University of Miami Law School University of Miami School of Law Institutional Repository

1981

\title{
The Third United Nations Conference on the Law of the Sea: the Ninth Session (1980)
}

Bernard H. Oxman

University of Miami School of Law, bhoxman@law.miami.edu

Follow this and additional works at: https://repository.law.miami.edu/fac_articles

Cart of the Law of the Sea Commons

\section{Recommended Citation}

Bernard H. Oxman, The Third United Nations Conference on the Law of the Sea: the Ninth Session (1980), 75 Am. Jl. Int'l. Law 211 (1981).

This Article is brought to you for free and open access by the Faculty and Deans at University of Miami School of Law Institutional Repository. It has been accepted for inclusion in Articles by an authorized administrator of University of Miami School of Law Institutional Repository. For more information, please contact library@law.miami.edu. 


\title{
THE THIRD UNITED NATIONS CONFERENCE ON THE LAW OF THE SEA: THE NINTH SESSION (1980)
}

\author{
By Bernard H. Oxman*
}

\section{INTRODUCTION**}

The ninth session of the Third United Nations Conference on the Law of the Sea met in New York from February 27 to April 4, and in Geneva from July 28 to August 29, 1980. In addition, the Drafting Committee met for 3 weeks in June in New York. ${ }^{1}$

At the end of the New York part of the session, the leadership ${ }^{2}$ issued a second revision of the Informal Composite Negotiating Text (ICNT/Rev. 2)..$^{3}$ At the resumed session, the text was revised again by the leadership and issued as the Draft Convention on the Law of the Sea (Informal Text) before the session closed. ${ }^{5}$ The issuance of both texts was preceded by debate in Plenary on the textual revisions proposed by the various chairmen.

The general perception was that the new informal text of the Draft Convention brings a decade of informal negotiation closer to completion. The conference had decided earlier, however, to defer further consideration of three important matters to the tenth session: (1) completion of the resolution setting up a commission to prepare for the establishment of the Inter-

* Professor of Law, University of Miami School of Law. United States Representative and Vice Chairman of the U.S. delegation, and Chairman of the English Language Group of the Drafting Committee, at the ninth session of the Law of the Sea Conference. The views expressed herein are those of the author and do not necessarily represent the views of the Department of State, the U.S. Government, or the English Language Group or Drafting Committee of the conference.

** This article was completed prior to the issuance of the following statement by the Department of State on March 2, 1981:

After consultations with the other interested Departments and Agencies of the United States Gov ernment, the Secretary of State has instructed our representative to the UN Law of the Sea Conference to seek to ensure that the negotiations do not end at the present session of the Conference, pending a policy review by the United States Government. The interested Departments and Agencies have begun studies of the serious problems raised by the Draft Convention, and these will be the subject of a thorough review which will determine our position toward the negotiations.

1 This article is a sequel to Stevenson \& Oxman, The Preparations for the Law of the Sea Conference, 68 AJIL 1 (1974); The Third United Nations Conference on the Law of the Sea: The 197. Caracas Session, 69 AJIL 1 (1975);-The 1975 Geneva Session, 69 AJIL 763 (1975); and Oxman, The Third United Nations Conference on the Law of the Sea: The 1976 New York Sesvion, 71 AJIL 247 (1977);-The 1977 New York Sessions, 72 AJIL 57 (1978);-The Seventh Sission (1978), 73 AJIL 1 (1979);--The Eighth Session (1979), 74 AJIL 1 (1980).

2 The procedure is set forth in UN Doc. A/CONF.62/62 (1978), 10 ThIRD UN Conference on the Law of the SeA, Official Records 6 (1978) [hereinafter cited as Off. Rec.], discusied at 73 AJIL 3-5 and 74 AJIL 2.

"UN Doc. A/CONF.62/WP.10/Rev.2 (1980).

- Following the same procedure. See note 2 supra.

"UN Doc. A/CONF.62/WP.10/Rev.3, and Add.1 and Corrs. 1-6 (1980) [hereinafter referred to in the text as the Draft Convention and in notes as DC(IT)]. 
national Sea-Bed Authority and to draft its provisional rules, regulations, and procedures (the Preparatory Commission); ${ }^{6}$ (2) protection upon entry into force of the Convention for investments in seabed mining made prior to entry into force of the Convention (generally referred to as preparatory investment protection), ${ }^{7}$ and (3) determining what entities, in addition to states, may become party to the Convention (participation). In addition, some more work was contemplated on delimitation of the economic zone and continental shelf between states with opposite or adjacent coasts. ${ }^{8}$

In light of the progress made at the ninth session, the conference scheduled 7 weeks of work for the Drafting Committee followed by a 6- or 7-week session of the conference itself in hopes of completing the final text of the Convention in 1981. A session would then be held in Caracas for signature, statements for the record, and other formalities.

Efforts were made by all concerned to ensure that the enactment of deep seabed mining legislation by the United States ${ }^{9}$ and the Federal Republic of Germany ${ }^{10}$ would not divert the resumed ninth session from completing work on the Convention. Thus, on the first day the Group of 77 made a strongly worded statement condemning such legislation, tc which the United States and the Federal Republic responded, ${ }^{11}$ and other delegations also made statements; but all attempted to avoid a lengthy rehashing of already familiar arguments.

While it may be that enactment of the legislation had an impact on some aspects of the negotiations (such as the decision to defer consideration of preparatory investment protection), in general it was not allowed to interfere with the negotiating process. This may be partly because the U.S. delegation made clear that its negotiating objectives had not changed from what they had been at the first part of the ninth session, and partly because the U.S. legislation deferred full-scale commercial mining until January 1, 1988, which allows time for the Convention to enter into force first.

A serious obstacle to completion in the near future of a Convention that can be widely accepted is the idea that it will be possible to resolve an important issue-be it one of those still outstanding or any other-by voting during formal proceedings. No better textual evidence of this can be found than the footnote to the new Article 309 prohibiting reservations that are not expressly permitted by another article: it begins, "This article is based on the assumption that the Convention is adopted by consensus." In effect, the footnote qualifies every article of the Draft Convention. Voting on any element of the "package deal" is likely to cause general collapse.

6 The report of the President regarding work on the Preparatory Commission is contained in UN Doc. A/CONF.62/L.55 and Corr.I (1980). The resumed ninth session deferred consideration of the matter.

${ }^{7}$ The U.S. proposal on the subject is set forth in Conf. Doc. IA/1 (1980).

${ }^{8}$ See DC(IT) Arts. 74, 83, 121, and 309.

${ }^{9}$ Deep Seabed Hard Mineral Resources Act, Pub. L. No. 96-283, 94 Stat. 553 (1980), reprinted in 19 ILM 1003 (1980).

${ }^{10}$ Act on Interim Regulation of Deep Seabed Mining, in force Aug. 17, 1980, [1980] BGB 1.I 1429, reprinted in 19 ILM 1330 (1980).

${ }^{11}$ The debate took place on July 28, 1980. UN Doc. A/CONF.62/SR.121 (1980). 
The author discussed this problem in greater detail in reporting on the eighth session. ${ }^{12}$

In this connection, the Convention may be most threatened by efforts to hold it hostage to political objectives outside the scope of the conference, as reflected in the polemical "transitional provision" regarding dependencies and occupied areas that appears after the text of the Convention and in proposals to allow liberation movements to become party to the Convention. Nothing will be achieved by pressing either objective. If the proponents prevail at the conference, there will be no widely accepted Convention to legitimize or implement their pyrrhic victory. The only winners would be those who hope to block widespread acceptance of the Convention but may be unable or unwilling to do so directly.

The new texts on deep seabed mining are legion; they are an enormous achievement, capping 3 years of work since the issuance of the ICNT ${ }^{13}$ and the near collapse of the conference. These texts, however, have not allayed all concerns regarding the deep seabed mining regime. Reluctance to reopen the texts to consideration at this stage is understandable. Nevertheless, the fact that protection for investments made prior to the entry into force of the Convention remains to be dealt with may provide a useful opportunity to ease some of the remaining concerns of potential deep seabed producers. It would be a shame if ideology stood in the way of arriving at practical arrangements that could enhance the prospects for ratification and early entry into force of the Convention. ${ }^{14}$ Failure to give reasonable assurances in the Convention will not prevent mining outside the Convention; it will only increase the chances that such mining will occur.

\section{The First Committee: Deep Seabed Mining}

The major achievement of the ninth session was the emergence of a generally advanced basis for accommodation on deep seabed mining. The Draft Convention in effect continues the process begun with the first revision of the ICNT. ${ }^{15}$

Many of the remaining noninstitutional issues were considered at length during the first part of the ninth session. Results were reflected in the ICNT/ Rev.2. The second part of the session was devoted in large measure to the central feature of the institutional problem: voting in the Council of the Sea-Bed Authority. A number of remaining noninstitutional problems were also addressed. In order to assess the more important of the many textual changes, it may be useful first to review briefly the elements of the package deal regarding seabed mining that emerged from the proposals made by Secretary of State Kissinger in 1976.

The crux of the settlement is the system of exploration and exploitation. The objective of the "parallel system" is to give states and private companies

12 74 AJIL 46-47.

${ }^{1.3}$ Informal Composite Negotiating Text, 8 OFF, REC., UN Doc. A/CONF.62/WP.10 and Add.1 (1977), reprinted in 16 ILM 1108 (1977).

14 See $73 \mathrm{AJIL}$ at $32 \mathrm{n} .11$ regarding the ideological question.

${ }^{15}$ ICNT/Rev.1, UN Doc. ANCONF.62/WP.10/Rev.1 (1979), reprinted in 18 ILM 686 (1979). 
sponsored by states on the one hand, and the new international Enterprise (the commercial mining arm of the Sea-Bed Authority) and its partners on the other hand, a genuine opportunity to mine the deep seabeds. Thus, a state or private applicant for a mine site must propose two sites, one of which would be "reserved" for mining by the Enterprise or developing countries. The Enterprise would have the right to obtain mining technology under fair and reasonable commercial terms and conditions from state and private miners if such technology is found not to be obtainable on the open market.

All mining would generate revenues for distribution by the A tuthority to developing countries, partly in the form of payments proportional to production and profits paid by miners on the "nonreserved side," and partly in revenues from the Enterprise.

One element of the settlement is that the parallel system would become subject to review after about 20 years. A further element is an interim limitation on the rate of expansion of production of minerals from seabed nodules (as well as provision for direct assistance to developing land-based producers to be drawn from the Authority's revenues); thus, land-based producers of these minerals would be afforded protection against sudden and extreme alterations in supply from this new source in proportion to aggregate world demand.

The new International Sea-Bed Authority would administer the system and adopt necessary nondiscriminatory ground rules, including regulations regarding such matters as environmental protection and safety. However, the Authority would not have the broad discretionary powers associated with some regulatory agencies in the United States or other countries. It would not have discretionary power to control entry, assign markets, fix prices, or otherwise intervene in opposition to market forces. The effort to ensure that the Authority could not do these things indirectly explains many aspects of the negotiations, particularly the emphasis on specificity in the allocation of functions to organs of the Authority, protection for market economy countries in the decision-making procedures of the Council, and compulsory and binding third-party settlement of disputes.

Much of the negotiation regarding the system of exploitation was designed to ensure that each "side" of the parallel system was given a fair opportunity to succeed. Supporters of the "private side" feared that the Enterprise would be given decisive advantages by the Sea-Bed Authority, and therefore sought to restrain the potential for disincentives to mining on the "private side." Supporters of the Enterprise feared monopoly control of technology by states and private companies that oppose the Enterprise, and therefore sought to ensure that the Enterprise would receive the necessary capital and technology to function independently or to bargain from strength in making joint arrangements. Some delegations endeavored to redirect this negative approach to the problem of balance into a positive one by giving each "side" some interest in promoting (or at least not frustrating) the success of the other.

Complicating this process were conflicting (but understandably cautious) assumptions about the nature of the interests likely to dominate the Sea- 
Bed Authority and the mining system. For potential seabed mining countries, a basic concern was to prevent extremist ideologues and land-based producers from combining to use the various powers of the Sea-Bed Authority to restrain private mining. For land-based producers and developing countries, a basic concern was to prevent the private companies of a few countries from dominating both sides of the parallel system, preempting competition, and using the international status of the Enterprise as the spearhead of efforts to gain artificial competitive advantages for seabed mining relative to land-based mining. ${ }^{16}$

Against this background, a necessarily brief exposition of the results of the ninth session regarding part XI of the text and the relevant annexes might focus on the list of outstanding issues set forth by the author at the end of the eighth session. ${ }^{17}$

\section{Article 140: sharing of benefits with "peoples who have not attained full independence or other self-goverming status"}

While the text of Article 140 has not been changed, the rules, regulations, and procedures implementing it must be approved by both the Assembly and the Council of the Authority, the latter functioning by consensus. ${ }^{18}$

\section{Article 150: making clear that the provisions on policies relating to activities} in the Area shall be implemented as specifically provided in this part

The words "as specifically provided in this Part" have been added to the chapeau of Article 150. This makes clear that Article 150 does not contain a separate set of requirements regarding seabed mining or a separate grant of power to implement the policies it sets forth, but rather contains a set of policy objectives for states parties and competent organs of the Authority in exercising the specific powers and functions conferred on each of them by other articles.

The list of policies has been augmented to include "the development of the common heritage for the benefit of mankind as a whole" as an independent objective. ${ }^{19}$

\section{Article 151: agreement on the numbers in the production ceiling}

The ICNT/Rev.1 specified a limitation on nickel production for an interim period of, at most, 20 years from the time deep seabed commercial

${ }^{16}$ This concern even applies to some industrial states like the USSR and France that feel they may not be among the first and largest seabed mining countries.

1774 AJIL 6-7.

${ }^{18} \mathrm{DC}(\mathrm{IT})$ Arts. 160(2)(f)(i), 161(7)(d), and 162(2)(n)(i). The same decision-making procedures also apply to the implementation by the Authority of Article 82, paragraph 4 on the distribution of payments to developing states parties in respect of mineral exploitation of the continental shelf seaward of 200 miles.

${ }^{19}$ Agreement on this consumer-oriented policy was made possible by including an additional policy that conditions of market access for imports of deep seabed minerals "shall not be more favourable than the most favou rable applied to imports from other sources." While there was discussion of broader prohibitions on subsidies, the technical difficulties encountered were considerable. 
production began.$^{20}$ For any given year, the overall production ceiling was to be projected on the basis of the total increase in annual nickel consumption for the 5 years prior to the commencement of commercial production from the deep seabeds, plus 60 percent of the increase in nickel ${ }^{21}$ consumption thereafter. ${ }^{22}$

Industrialized countries were concerned about the effect of the interim production limitation in periods of low growth. They felt that the production ceiling should not be permitted to drop below a certain minimum, ${ }^{23}$ lest it have serious inhibiting effects on investment. The minimum ceiling would therefore be calculated as if the annual increase in nickel consumption were 3 percent, provided the resulting ceiling does not for any given year exceed the total projected increase in nickel consumption. ${ }^{24}$ Provision is also made for annual variations in production levels at the discretion of the miner, and for obtaining a supplementary production authorization for more substantial or sustained increases in production. ${ }^{25}$

The ICNT/Rev. 1 reflected the generally accepted principle that once a plan of work containing planned production levels was approved, the Authority could not impose a change in the production levels permitted in that plan of work. The new text preserves that principle, but moves the date of computation closer to the date the miner plans to begin commercial production. ${ }^{26}$

The text ${ }^{27}$ also provides that the

Authority shall issue a production authorization for the level of production applied for [by the operator] unless the sum of that level and the levels already authorized exceeds the nickel production ceiling, as calculated ... in the year of issuance of the authorization, during any year of planned production falling within the interim period [during which the nickel production ceiling is in effect].

This "split contracting system" permits a miner to obtain his contract first and production authorization later. By separating the two procedures, it avoids artificial pressure to compete prematurely for portions of the production ceiling, reduces the risk that investment in exploration will be lost

\footnotetext{
${ }^{20}$ See Art. 151 of ICNT/Rev.1, Rev.2, and DC(IT).

${ }^{21}$ For economic and technical reasons, a limit on nickel production would affect overall production of other metals in the polymetallic nodules (copper, cobalt, and manganese). Rules and regulations can be adopted to ensure that the relevant proportions of production of other metals from nodules are not exceeded. DC(IT) Art. 151, para. 2(f).

22 The projections are derived from "trend lines" based on the most recent 15-year period for which actual nickel consumption data are available. Id., para. 2(b). These trend lines are computed for each plan of work at the time the production authorization is issued for that site, which may not be more than 5 years prior to the start of commercial production under that plan of work.

${ }^{23}$ This minimum was called a "floor," a misunderstood term. It is neither a min mum guaranteed level of seabed production nor a minimum guaranteed market share for stabed production, but rather a minimum limit on the ceiling for seabed production.

${ }^{24} \mathrm{DC}(\mathrm{IT})$ Art. 151, para. 2(b)(iv). $\quad{ }^{25} I d$. . para. 2(e).

${ }^{26}$ A maximum of 5 years before commercial production begins is specified.

${ }^{27}$ DC(IT) Art. 151, para 2.
} 
because production needs to be deferred, and permits more timely computation of the ceiling for issuing a production authorization for each miner.

The ICNT/Rev. 1 reflected general agreement that the Authority should have the right to participate in commodity conferences dealing with commodities produced from resources of the deep seabeds. ${ }^{28}$ The new text prohibits the Authority from taking part in an unbalanced forum by making participation by "all interested parties including both producers and consumers" a condition of participation by the Authority. ${ }^{29}$ Over time, this provision might act as a restraint on possible attempts to form a cartel even if some seabed producers come to regard such an arrangement with favor. The text was also amended to emphasize that the basis of the Authority's participation, including possible voting power, is left to the rules of procedure of the organs established by the particular commodity agreement. ${ }^{30}$

\section{Avticle 155, paragraph 6: the moratorium}

Review of the system of exploitation after some 20 years was a basic element of the package under negotiation. Since the review conference was designed to allay developing countries' concerns that they might be agreeing to a system that might not turn out to be in their long-range interests, the question of incentives for seabed mining countries to negotiate at the review conference arose.

At the suggestion of various developing country representatives, the ICNT/Rev.I provided that if the review conference could not reach agreement on the system of exploration and exploitation within 5 years, the Assembly of the Authority could decide that "no new contracts or plans of work for activities in the Area shall be approved" pending such agreement. ${ }^{31}$ The industrialized states rejected the idea that a moratorium was an appropriate alternative to agreement.

The compromise reached eliminates the power to impose a moratorium. As an alternative, it permits two-thirds of the parties in effect to revive a procedural situation similar to that which exists now: they may insist that a different sy'stem of exploitation is an essential element of any convention on the law of the sea, and others may decide whether they wish to be parties to it under such circumstances. Thus, if agreement is not reached on the system of exploration and exploitation within 5 years, the review conference may adopt amendments to the system by a two-thirds vote; these amendments would enter into force for all parties 1 year after being ratified by two-thirds of the states parties. ${ }^{32}$ The 1-year delay corresponds to the 1 year notice required for states to denounce the Convention. ${ }^{33}$ The amend-

${ }^{2 *}$ ICNT Art. 151, para. 1.

${ }^{29} \mathrm{DC}(\mathrm{IT})$ Art. 15I, para. 1.

" DC(IT) Art. 151, para. 1 specifies that the Authority's participation is "in respect of production in the Area," rather than "in respect of the production in the Area" as in the ICNT/ Revi. 1 (emphasis added).

31 ICNT/Rev. I Art. 155, para. 6. $\quad 32$ DC(IT) Art. 155, para. 4.

s. $\mathrm{DC}(\mathrm{IT})$ Art. 3I 7. It is assumed that the United States would denounce the Convention if a new system of exploration and exploitation that the United States had not ratified were to enter into force. 
ments may not in any event affect rights acquired under existing contracts. $^{34}$

The expansion of global dependence on seabed minerals, as well as the mere existence of the Convention for 20 years, is likely to promote restraint among all concerned. Any substantial revision over the objection of major consuming or seabed mining countries would effectively destroy both the moral and practical significance of any possible argument that exploitation outside the Treaty is impermissible.

\section{Article 161: voting in the Council (including Article 162, paragraph 2(j))}

Voting in the Council of the Sea-Bed Authority was the most difficult issue addressed by the ninth session of the conference.

Composition. The question of the composition of the Council was regarded as largely settled by the earlier texts. It is clearly linked, of course, to the issue of voting.

The 36 members of the Council must include:

(a) Four members from among the eight States Parties which have the largest investments in preparation for and in the conduct of activities in the Area, either directly or through their nationals, including at least one State from the Eastern (Socialist) European region;

(b) Four members from among those States Parties which, during the last five years for which statistics are available, have either consumed more than two per cent of total world consumption or have had net imports of more than two per cent of total world imports of the commodities produced from the categories of minerals to be derived from the Area, and in any case one State from the Eastern (Socialist) European region;

(c) Four members from among countries which on the basis of production in areas under their jurisdiction are major net exporters of the categories of minerals to be derived from the Area, including at least two developing countries whose exports of such minerals have a substantial bearing upon their economies;

(d) Six members from among developing States, representing special interests. The special interests to be represented shall include those of States with large populations, States which are land-locked or geographically disadvantaged, States which are major importers of the categories of minerals to be derived from the Area, States, which are potential producers of such minerals, and least developed States. ${ }^{35}$

Furthermore, the 18 members "elected according to the principle of ensuring an equitable geographical distribution of seats in the Council as a whole" must include at least one member from each geographical region: "Africa, Asia, Eastern Europe (Socialist), Latin America and Western Europe and others."36

${ }^{34} \mathrm{DC}(\mathrm{IT})$ Art. 155, para 5.

${ }^{35}$ ICNT/Rev.1 and DC(IT) Art. 161, para. 1.

${ }^{36} \mathrm{Ibid}$. The general expectation is that the six non-Communist seats in categories (a) and (b) will be filled by the United States, Japan, and four Western European countries (probably 
The new text provides that each group seated on the Council "is represented by those members, if any, which are nominated by the group." 37 This text was added primarily to ensure the representative character of the substantive interest groups referred to in subparagraphs (a), (b), and (c) of Article 161(1). There would have been no need for such special provision for regional group members alone, given the United Nations custom (followed at the conference and in UN organs generally) of deferring to the nominees of the regional groups, if any, in such situations.

Voting. The basic voting issue was whether Western seabed mining countries could be reasonably assured that decisions, at least on the more important matters, could not be made over their objection. The question therefore became one of blocking votes.

Two approaches were generally considered. Both dealt with requirements additional to the numerical percentage requirements for making decisions, be it two-thirds or three-fourths. The first was a two-tiered approach under which substantive decisions required a two-thirds affirmative vote in the Council (including an absolute majority of its members), provided that with respect to the more important of these questions a fixed number of states did not cast negative votes. ${ }^{38}$ The second approach would have substituted for the blocking vote of a fixed number of states a requirement that the Council majority include states representing 50 percent of the total consumption and 50 percent of the total production (on land and offshore) by all states parties of minerals belonging to the categories of minerals produced from the deep seabeds. Thus, the second approach would have provided a blocking vote for the major consumers and producers.

including the Federal Republic of Germany, France, and the United Kingdom). Noting the possibility that category (c) may include major Western exporters (such as Canada), Sweden and some other Western countries that may not qualify for these categories believe they are at a disadvantage in seeking election to the Council if the criterion is not equitable geographic distribution from among all those elected outside any particular category, but equitable geographical distribution of seats in the Council "as a whole." Because of their proportionately large contributions to financing the Enterprise, they believe they should have a better chance of being represented on the Council than the traditional allocation of seats among UN regional groups is likely to yield.

While sympathetic to such arguments, the United States and other delegations were forced to assume that any effort to require more Western seats on the Council would stimulate demands for a general expansion to add "proportional" numbers of other seats. Undesirable even in principle, the expansion could unacceptably dilute the protection afforded major seabed mining states by various voting provisions. Accordingly, they opposed the change.

Needless to say, the problem was presented as if the term "equitable geographical distribution" were to be applied without regard to the particular context of this Convention. It also proceeded on the assumption that a particularly important role is not envisaged in the administration of the Enterprise for technologically advanced Western consumer countries lacking substantial independent seabed mining or land-based producer interests. In reality, at least one of the assumptions is likely to be inaccurate.

${ }^{37} \mathrm{DC}(\mathrm{IT})$ Art. 161, para. 2(c).

${ }^{38}$ This approach was incorporated in principle in the WG21 report issued at the end of the eighth session. Report on negotiations held by the Chairman and the Co-ordinators of the Working Group of 21, UN Doc. A/CONF.62/91, at 16 (1979) (setting forth UN Doc. A/CONF.62/C.1/L.26 (1979). 
The strong ideological opposition of the African Group and others to "weighted voting" made negotiation on the second approach difficult even though it is not a weighted voting formula as such. ${ }^{39}$

Negotiation on the basis of the first formula produced a complex stalemate among the three groups principally concerned. The major Western deep seabed mining countries refused to accept a result that did not give them a blocking vote (no more than five or six votes to block). Even if they would have agreed to the Western position in the end, the developing countries refused to accept a blocking number low enough to give the Eastern European countries an independent blocking vote (three or four votes to block). Finally, the Soviet Union refused to agree to the concept of a blocking vote if it would give blocking power to the Western countries but not to the East European countries. ${ }^{40}$

The resultant compromise is a three-tiered voting system for substantive issues. ${ }^{41}$

(1) For those issues where special voting protection for minority interests is unlikely to be needed, decisions require a two-thirds majority of the Council members present and voting.

(2) For those decisions requiring additional assurance-of broad support, a three-fourths majority of the Council members present and voting is required. Decisions in this category are generally executive or operational (occasionally even ministerial) rather than legislative or rule making in nature. They are the kind that judges - whatever their legal backgroundhave little difficulty reviewing for compatibility with relevant legal requirements (in this case, the provisions of the Convention, the rules, regulations, and procedures, and the terms of contracts).

The requisite majority of members present and voting must in both cases include the affirmative votes of at least a majority of the members of the Council, i.e., at least 19 affirmative votes.

(3) The "implementation of its functions as prescribed in Part XI" is effected by the Authority by the adoption and uniform application of "rules, regulations and procedures." ${ }^{.22}$ The essence of the voting settlement is that the adoption of "rules, regulations and procedures" by the Authority requires a consensus in the Council. ${ }^{43}$ Consensus is also required to adopt

\footnotetext{
${ }^{39}$ The African ideological position might have been less rigid had the Africz.n land-based producers devoted more attention to their voting power.

${ }^{40}$ Abortive attempts were made by some delegates to break the impasse by finding alternative means to deal with the Soviet problem, such as blocking power for a unanimous regional group. Developing countries rejected any such veto for a single regional group in light of their opposition in principle to approaches analogous to the right of veto in the UN Security Council.

${ }^{41}$ DC(IT) Art. 161, para. 7.

${ }^{42}$ Ann. III, Art. 17, para. 1. It is in this manner that the detailed requirernents for exploration and exploitation not set forth in the Convention itself (or in its annexes) are elaborated and changed. A detailed list of some of these, and relevant criteria, is contained in Annex III, Art. 17. Agreement on the consensus rule was accompanied by agreement that the list is not exhaustive. The words "inter alia" were added to the chapeau. The Draft Convention also adds general subject matter criteria for, and unifies the provisions on approval of, rules, regulations, and procedures. DC(IT) Arts. 160, para. 2(f) and 162, para. 2(n).

${ }^{43}$ DC(IT) Art. 161, para. 7(d), (f), and (g).
} 
amendments, to take measures to protect land-based producers of minerals, to determine the voting majority needed for any decision for which the Convention does not specify the requisite majority, and to decide that a lesser majority is sufficient if a question arises as to whether the requisite majority needed to make a decision is consensus. For these purposes, "consensus' means the absence of any formal objection." 44

A consensus system, of course, protects all concerned against adverse decisions. However, it does not protect against adverse failure to make a decision. ${ }^{45}$ To the extent the Convention requires that a decision be made, the problem may be reduced in part by the specificity of the requirement and in part because dispute settlement procedures would be available. Nevertheless, two basic prerequisites for mining to occur under the Convention necessitated special attention in light of this problem.

First, in the absence of necessary rules, regulations, and procedures, it would not be possible for the mining system to operate. Thus, the provision in the final clauses that the "rules, regulations and procedures drafted by the Preparatory Commission shall apply provisionally pending their formal adoption by the Authority in accordance with Part XI"46 is clearly an integral aspect of the First Committee's settlement.

The second problem concerns approval of plans of work (contracts) for exploration and exploitation. If approval of a plan of work requires Council review, how does one reconcile the objective nature of the contracting system set forth in immense detail in the Convention with the political character of a Council that intentionally includes some members whose immediate national interests may not be served by seabed mining?

Article I62(2) (j) of the ICNT dealt with the problem by specifying that the "plan of work shall be deemed to have been approved unless a decision to disapprove it is taken within 60 days of its submission by the Technical Commission." The text proposed in the report of the Working Group of 21 issued at the end of the eighth session ${ }^{47}$ and repeated in the ICNT/Rev.2 substantially changed this procedure by providing that "a plan of work shall be deemed to have been approved unless a proposal for its approval or disapproval has been voted upon within . . . 60 days." This change was rejected by the Western seabed mining states.

Under the Draft Convention, the applicable procedure in the Council depends upon the recommendation of the Legal and Technical Commission. The Commission is required to "submit appropriate recommendations to the Council" on plans of work, and to "base its recommendations solely on the grounds stated in annex III," in a detailed report. ${ }^{48}$ Its decision-mak-

4 Art. 161, para. 7(e). When it is apparent that there will be a formal objection to a proposal, provision is made for ad hoc conciliation committees composed of Council members that are to endeavor to work out a proposal that can be adopted by consensus. Ibid.

1s Except perhaps indirectly through the bargaining process.

4h DC(IT) Art. 308, para. 4. ${ }^{47}$ Note 38 supra.

${ }^{4 k}$ DC(IT) Art. 165, para. 2(b). Annex III, Article 6(3) requires approval of plans of work that "conform to the uniform and non-discriminatory requirements established by the rules, regulations and procedures of the Authority, unless": (1) a previous miner has received or is being considered for a plan of work for part of the area applied for; (2) part of the area ap- 
ing procedures will be specified in the rules, regulations, and procedures of the Authority; ${ }^{49}$ the matter will thus be taken up by the Preparatory Commission.

If the Commission recommends Council approval, after about a month for ad hoc conciliation if necessary, "the plan of work shall be deemed to have been approved by the Council unless the Council disapproves it by consensus." The "State or States, if any, making the application or sponsoring the applicant" are excluded from the deliberations on whether there is a consensus to disapprove the plan. ${ }^{50}$ If, on the other hand, the Commission recommends the disapproval of a plan of work or does not make a recommendation, then a three-fourths majority is necessary for Council approval. $^{51}$

\section{Article 188: providing access to commercial arbitration for contractual disputes}

Article 188 of the ICNT/Rev.1 provided for submission of disputes under a contract or plan of work to commercial arbitration insofar as provided in a contract between the parties. The new text requires that such disputes be submitted, "at the request of any party to the dispute, to binding commercial arbitration" unless otherwise agreed by the parties. ${ }^{52}$ The arbitral tribunal may deal with disputes concerning the interpretation or application of the contract, but may not directly decide a question it identifies as one of interpretation of the Convention itself. Accordingly, provisions protecting the rights of the operator are likely to be included in the contract itself even if those rights might in any event be protected by the Convention.

\section{Annex II, ${ }^{53}$ Article 4: sponsorship where nationality and control are separated}

The ICNT/Rev. 1 left in doubt how divisions between nationality and control of an applicant would be identified and handled.

The Draft Convention specifies that sponsorship of an applicant by the state of nationality is sufficient:

(1) "unless the applicant has more than one nationality, as in the case of a partnership or consortium of entities from several States, in which event all States Parties involved shall sponsor the application"; or

(2) "unless the applicant is effectively controlled by another State Party or its nationals, in which event both States F'arties shall sponsor the application." 54

plied for has been disapproved by the Council for mining because of serious environmental risks; or (3) the sponsoring state would thereby exceed the antimonopoly limits.

${ }^{49} \mathrm{DC}(\mathrm{IT})$ Art. 163, para. $11 . \quad{ }^{50} \mathrm{DC}$ (IT) Art. 162, para. 2(j)(i).

${ }^{51} \mathrm{DC}(\mathrm{IT})$ Art. 162, para. 2(j)(ii).

${ }^{32}$ In the absence of agreement to the contrary, and unless others are prescribed by the rules, regulations, and procedures of the Authority, the UNCITRAL rules apply.

${ }^{53}$ Annex II of the ICNT/Rev.1 became Annex III of the ICNT/Rev.2 and the DC(IT) as amended.

${ }^{54}$ DC(IT) Ann. III, Art. 4, para. 2. 
The rules, regulations, and procedures of the Authority will set forth "the criteria and procedures for implementation of the sponsorship requirements." 55 In this connection, the Convention specifies that the duty of a sponsoring state to ensure compliance with the Convention is fulfilled if it adopts laws and regulations and takes administrative measures "which are, within the framework of its legal system, reasonably appropriate for securing compliance by persons under its jurisdiction." 56

These provisions were not written in connection with, or in derogation of, the provisions of part VII of the Convention with respect to the nationality of ships and the duties of the flag state, and of part XII with respect to pollution from ships. The flag state and the sponsoring state, if different, are presumably obliged to avoid interfering with each other's fulfillment of relevant obligations within their respective spheres of primary concern. ${ }^{57}$

\section{Annex II, ${ }^{38}$ Article 5 on technology transfer: the Brazil clause, time limits, dispute settlement recourse for third-party owners, and avoidance of warranty implications}

The technology transfer provisions have been reorganized and redrafted to avoid several problems with the earlier text. Among the more important changes are:

- The obligation of miners to transfer seabed mining technology they use to the Enterprise on fair and reasonable commercial terms and conditions, if it is not available on the open market, ends 10 years after the Enterprise begins commercial production..$^{59}$ While the United States and others sought a shorter period than 10 years, the compromise included assurances by the developing countries that they will no longer press for the transfer of processing technology.

- The new text eliminates a provision on blacklisting of a third-party owner of technology who refuses to honor his assurance to transfer to the Enterprise, on fair and reasonable commercial terms and conditions, technology he owns that is used by the miner and is not generally available on the open market. ${ }^{60}$

- In cases of third-party ownership of technology used by a miner, a duty is placed on the miner to obtain the right to transfer technology "whenever it is possible to do so without substantial cost to" him, a particularly relevant situation being "cases where there is a substantial

55 lbid.

${ }^{56}$ Id., para. 3.

${ }^{57}$ A more interesting question perhaps is the influence the ideas contained in this new article and its implementing regulations may have in the future on the application of the concept of "genuine link" not only to ships but in general, and the relevance to other efforts to find fair and effective jurisdictional techniques for dealing with multinational corporations.

5* See note 53 supra. ${ }^{59} \mathrm{DC}(\mathrm{IT})$ Ann. III, Art. 5, para. 7.

"See ICNT/Rev.l Ann. II, Art. 5, para. 1(b). Since the technology is by definition not generally available on the open market, compensation for the value inherent in its restricted availability would certainly seem relevant in determining fair and reasonable commercial terms and conditions. A miner does not lose or give away his exclusive use of technology; he sells it for fair value. 
corporate relationship between the operator and the owner of the technology." 61

The failure to eliminate completely the obligation to transfer technology to a developing country under the so-called Brazil clause ${ }^{62}$ may be the most controversial aspect of the resultant text. Those who opposed its elimination argued that it applies only with respect to a reserved site proposed by the miner himself, and then only if it "would not involve transfer of technology to a third State or the nationals of a third State," and that it is further restricted by the overall 10-year time limit on the technology transfer obligations of miners. They did agree, however, to the additional qualification that a miner's obligation to transfer technology to a developing country "shall only apply . . . where technology has not been requested or transferred by him to the Enterprise."63

\section{Annex $I I,{ }^{64}$ Article 7 on selection of applicants: the priority accorded the Enterprise by paragraph 4}

Under the ICNT, whenever a selection had to be made between an application for a plan of work by a state or private party and one by the Enterprise for a reserved area, priority was given to the Enterprise. ${ }^{65}$

Under the new text, the question of selection no longer affects approval of plans of work (contracts). ${ }^{66}$ The question would arise only if, at the end of any given 4-month period, approval of all the applications for a production authorization received during that period result in production in excess of the interim production limitation or a production limitation arising under a commodity agreement to which the Authority is party. In that case, in an effort to preserve the balance of the parallel system, the Enterprise would have priority to receive a production authorization with respect to a reserved area "whenever fewer reserved sites than non-reserved sites are under exploitation." 67 The private applicant who fails to receive a production authorization at the time would have priority in subsequent periods until one is awarded to him..$^{68}$

\section{Annex $I I,{ }^{69}$ Article 10 on joint arrangements: the failure to make clear that they have the same security of tenure as other contracts}

The new text provides that joint arrangements between a contractor and the Enterprise "shall have the same protection against termination, suspension or revision as contracts with the Authority."70

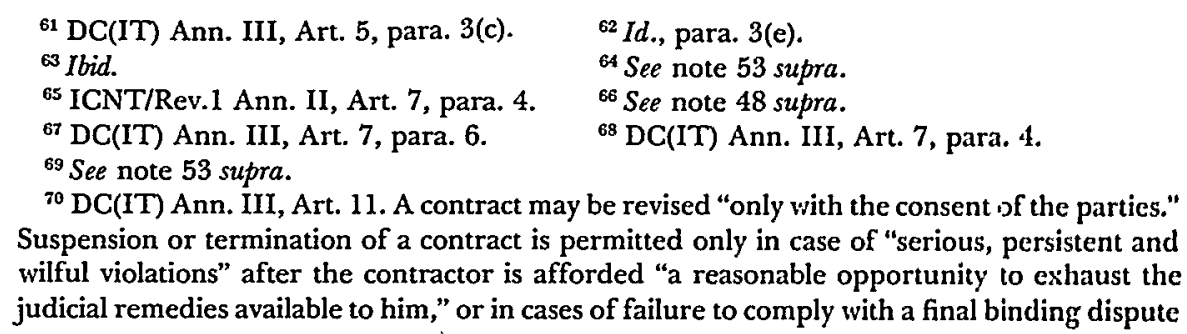
Suspension or termination of a contract is permitted only in case of "serious, persistent and wilful violations" after the contractor is afforded "a reasonable opportunity to exhaust the judicial remedies available to him," or in cases of failure to comply with a final binding dispute

${ }^{62} I d$., para. 3(e).

${ }^{64}$ See note 53 supra.

${ }^{68}$ See note 48 supra.

${ }^{68} \mathrm{DC}(\mathrm{IT})$ Ann. III, Art. 7, para. 4. 
11. Amnex III, ${ }^{71}$ Articles 10 or 11 on payments by the Enterprise: the failure to state that the Enterprise is liable for the same payments as the contractors, at least with respect to activities in nonreserved sites

The basic problem here was to ensure that the Enterprise did not enjoy a substantial economic advantage, unbalancing the parallel system by virtue of exemption from the obligation to make payments on production and profits to the Authority in the same amount as other miners. On the other hand, there was a perceived need to build up the reserves of the Enterprise.

The solution ${ }^{72}$ found was to retain all of the net income of the Enterprise in its reserves during an initial period required for it to become self-supporting. During that period, which is not to exceed 10 years from the commencement of commercial production by the Enterprise, it will also be exempt from making payments on production and profits to the Authority. After that initial period, however, the Enterprise (an independent commercial enterprise under Annex IV) will become liable for the same payments as contractors, and the Assembly will determine what portion of the remaining net income of the Enterprise (after such payments) is to be transferred to the Authority and what portion is to be retained in the Enterprise's reserves.

\section{Annex III, ${ }^{73}$ Article 10 on financing the Enterprise: the failure to require that payments and guaranties be in convertible currencies}

The text now requires that funds made available to the Enterprise be in "freely usable currencies or currencies which are freely available and effectively usable in the major foreign exchange markets." The freely usable currencies will be defined in the rules, regulations, and procedures of the Authority in accordance with prevailing international monetary practices. ${ }^{74}$

wtlement decision applicable to the contractor. DC(IT) Art. 153, para. 6; Ann. III, Arts. 18 and 19. Annex III, Article 18 was revised to make clear that monetary penalties are an alternatwe to vuspension or termination of a contract in all cases of contract violation.

"1 Aunex IIl of the ICNT/Rev.1 became Annex IV of the ICNT/Rev.2 and the DC(IT) as amended.

72 DC(IT) Ann. IV, Art. 10, para. $3 . \quad{ }^{73}$ See note 71 supra.

${ }^{71} \mathrm{DC}$ (IT) Ann. IV, Art. 11, para. 3(g). This provision is modeled after similar provisions uncluded in recent international commodity agreements and the Common Fund in response to the revision of the Articles of Agreement of the International Monetary Fund. See Art. 1, para. 9 of the Agreement Establishing the Common Fund for Commodities, UN Doc. TD/IPC/ CF/C.ONF/24 (1980); Art. XXX(f) of the Articles of Agreement of the International Monetary Fund, ws amended by Resolution 31-4 of the Board of Governors, effective April 1, 1978, UN D.s. IMF $(091) \mathrm{A} 7$.

A number of other improvements were made in the text on financing the Enterprise, While the basic provision that the Enterprise will initially be afforded the funds necesary tuesplore and exploit one mine site through interest-free loans and loan guarantees from thites parties is retained, the text now specifies that the draft rules, regulations, and procedure prepared by the Preparatory Commission shall include the precise overall amount and any criteria and factors for its adjustment. Id., para. 3(a). Thus, states will have a better idea of their precise obligations without its being necessary to deal with the question (including the problem of inflation) in the Convention. In addition, the financial obligations of any one state cannot exceed its percentage under the UN scale of assessments at the time, which has a maxi- 


\section{Annex III, Article 12: tax immunity for the Enterprise}

The ICNT/Rev.1 flatly stated that the "Enterprise, its assets, property, and revenues . . . shall be immune from taxation."75

The new text, in addition to permitting the Enterprise to waive its privileges, ${ }^{76}$ changes the taxation provision to read: "The Enterprise shall negotiate with the host countries in which its offices and facilities are located for exemption from direct and indirect taxation."77 The result is that states that desire to have Enterprise offices and facilities in their territory are free to offer tax incentives for this purpose, which, of course, they are free to do even in the absence of such a provision. Like any other business, the Enterprise would wish to seek and consider available tax relief in deciding where to locate its offices and facilities. ${ }^{78}$

In this connection, both a potential host state and, from an entirely different perspective, a potential business partner of the Enterprise will wish to reflect that while in principle the Enterprise is to be treated in the same way that a state treats "entities conducting business" within its territory, ${ }^{70}$ the Enterprise's property and assets are "immune from confiscation, expropriation, requisition, and any other form of seizure by executive or legislative action." 80 The private parties to joint venture contracts with the Enterprise may seek to avail themselves of these benefits in deciding on the allocation of title over vulnerable assets. Should this feature of the Convention have demonstrably positive effects on stimulating invest.ment in developing countries where there is otherwise a significant risk of expropriation, it could in time promote a more favorable attitude toward restraints on expropriation of other kinds of foreign investment in developing countries.

\section{The Antimonopoly Clause}

The French delegation continued to seek substantial increases in the socalled antimonopoly restrictions, with some support from the USSR, and opposition from the United States, West Germany, and the United Kingdom.

mum of $25 \%$ (the U.S. share). Voluntary measures to deal with any shortfall caused by the failure of all UN members to ratify can be adopted only by consensus in the Assembly. Id., para. 3(b) and (c). While states need to supply promissory notes for the full amount of their share of the total interest-free loans at the outset, the Enterprise will call up the funds under the notes gradually in accordance with a schedule reflecting its requirements Id., para. 3(d). Provision is made for preparing a schedule for repayment of the interest-free loans, Id., para. 3(f).

${ }^{75}$ ICNT/Rev.1 Ann. III, Art. 12, para. 5. ${ }^{76}$ DC(IT) Ann. IV, Art. 13, para. 7.

77 Id., para. 5.

${ }^{78}$ Questions also arise regarding the immunities of the Authority from taxation. These were resolved (DC(IT) Art. 183) by using the language of the Common Fund Agreement as a model. See Art. 48, paras. 1-3 of the Agreement Establishing the Common Fund, supra note 74.

${ }^{79} \mathrm{DC}(\mathrm{IT})$ Ann. IV, Art. 13, para. 4(d). $\quad{ }^{80} \mathrm{Id}$., para. 4(a). 
The previous criteria ${ }^{81}$ were slightly reformulated and two minor additions were made. ${ }^{82}$

\section{The Second Committee}

The main outstanding issues in the Second Committee identified by the author at the end of the eighth session were those concerning the continental shelf where it extends seaward 200 miles from the coast, and delimitation of the economic zone and continental shelf between states with opposite or adjacent coasts. ${ }^{83}$

\section{The Continental Shelf}

(1) Ridges. The Soviet delegation, supported by others, continued to press for clarification of the complex provisions regarding the outer limit of the continental shelf in areas of ridges. The concern centered on the desirability of making clear that the rule that the continental shelf may not extend further than 350 miles from the coast or 100 miles from the 2,500-meter isobath, whichever is further seaward, is intended as a limitation, not as a basis for extending the shelf beyond the outer edge of the continental margin as defined in the Convention by the Irish formula. ${ }^{84}$

From the perspective of some broad margin states, it was equally desirable to make clear that irregular features, howsoever named, that are natural components of the continental margin and satisfy the Irish formula can be used in applying the alternative 2,500-meter-plus-100-mile test.

Negotiations on this matter were successfully completed at the first part of the ninth session. The principle that the continental margin does not include "the deep ocean floor" was clarified by adding to that phrase the words "with its oceanic ridges," which make clear that the outer limit of the continental shelf is at the 200 -mile limit in such cases. ${ }^{85}$ Either the 350 -mile or the 2,500-meter-plus-100-mile test can be applied by a coastal state,

\footnotetext{
*1 ICNT/Rev.1, Ann. II, Art. 6, paras. 3(d) and 4.

${ }^{* 2}$ The scope of the clause was clarified to apply only to plans of work actually held by a state, not those that were approved but are no longer held by it, and only to nonreserved sites. DC(IT) Ann. III. Art. 6, para. 3(c). The "antidensity" clause was reformulated as $30 \%$ of a circular area of 400,000 square kilometers surrounding the center of the proposed site. Ibid. The percentage of the total unreserved area of the seabed that can be held was reduced from $3 \%$ to $2 \% .1 b i d$. A reference was added to avoiding "discrimination against any State or system" in cases of selection among applications for production authorizations. Id., Art. 7, para. 5. A new clause permits the Authority to adopt rules, regulations, and procedures to deal with cases where selection among competing applicants is necessary after the end of the period during which the interim production limitation is in effect (presumably because of limits in a commodity agreement to which the Authority is party). Id., Art. 6, para. 5. A consensus in the Council is of course required for adoption of such rules, regulations, and procedures. DC(IT) Arts. 161, para. $7(d)$, and 162, para. 2(n)(ii).

${ }^{*}$ See 74 AJIL at 7.

* See discussion in id. at 19-22; DC(IT) Art. 76.

${ }^{* 5}$ DC(IT) Art. 76, para. 3.
} 
assuming the Irish formula is satisfied, to "submarine elevations that are natural components of the continental margin, such as its plateaux, rises, caps, banks and spurs"; but in other cases, "on submarine ridges, the outer limit of the continental shelf shall not exceed 350 nautical miles from" the coast $^{86}$ even though the Irish formula might otherwise place the limit of the continental margin further seaward (see figure 1). These texts emerged after intensive discussions between broad margin states and the Soviet Union on new language and the effects of that language. ${ }^{87}$

(2) Sri Lanka's proposal for a special approach to determining the extent of its continental margin. A consensus statement of understanding will be appended to the Final Act of the conference. It sets forth a special method based on average thickness of sediment for determining the outer limit of the continental margin in the Bay of Bengal because of the peculiar effect of Article 76 on the characteristics of the continental margin in question, where there is a very broad continental rise beyond a very narrow shelf and slope. ${ }^{88}$ While not strictly a statement of interpretation, ${ }^{86}$ its intent is to reproduce a result in that area equivalent to the effect of applying Article 76 in the rest of the world. It is assumed that the Commission on the

${ }^{86} I d$., para. 6. An interesting question regarding these texts is when, if ever, a submarine ridge that is not a natural component of the continental margin is nevertheless part of the continental margin despite the exclusion from the continental margin of the "deep ocean floor with its oceanic ridges." It is possible that lying beneath the seeming contradiction there may be some subtle questions regarding the nature of evidence required and the ex:ent of the risk, particularly if sedimentary rock that may have broken off from the continental margin is discovered to have collected within ridge formations or is presently "hidden" by a basaltic layer. Thus, uncertainty as to whether a particular "submarine ridge" is an "oceaniz" ridge of "the deep ocean floor," or whether a particular sedimentary formation is part of the continental margin, would not have potentially sweeping consequences of extending jurisdiction the length of the ridge under the 2500-meter-plus-100-mile test, but might result "at worst" in extending jurisdiction from 200 miles to 350 miles, a lesser but nevertheless serious result.

${ }^{87}$ As a neighbor of the Soviet Union (the main proponent of an amendment on ridges), the United States ensured that there was in fact common understanding bezween the delegations regarding the effect of this language in relevant areas before supporting it.

The proposed paragraph 5 bis (now Article 76, paragraph 6) reads as follows:

Notwithstanding the provisions of paragraph 5 , on submarine ridges, the outer limit of the continental shelf shall not exceed 350 nautical miles from the baselines from which the breadth of the territorial sea is measured. This paragraph does not apply to submarine elevations that are natural components of the continental margin, such as its plateaux, rises, caps, banks and spurs.

The U.S. Representative, Ambassador Richardson, made the following st atement on the record in Plenary on April 3, 1980:

Our support for the proposal regarding the continental shelf contained in Ambassador Aguilar's report rests on the understanding that it is recognized - and to the best of our knowledge there is no contrary interpretation - that features such is the Chukchi plateau situated to the north of Alaska and its component elevations cannot be considered a ridge and are covered by the last sentence of the proposed paragraph 5 bis.

Interested delegations were notified in advance that the statement would be rade. There was no dissent as to its substance.

${ }^{88}$ See Conf. Doc. C.2/Informal Meeting/65 (1980).

${ }^{89}$ The technique of a consensus statement of understanding was used beciuse some delegations were reluctant to reopen discussion of the text of the Convention on the limits of the continental shelf. 
Figure 1

DIAGRAM OF ARTICLE 76

Limit of continental shelf may not extend beyond further seaward of either natural prolongation of land

200 miles from baseline (coast) territory to outer edge of continental margin

continental margin does not include deep ocean floor with its oceanic ridges continental margin comprises submerged prolongation of land mass, and consists of shelf, slope and rise

coastal state may establish outer edge of continental margin by straight lines (up to 60 miles long) connecting points located either

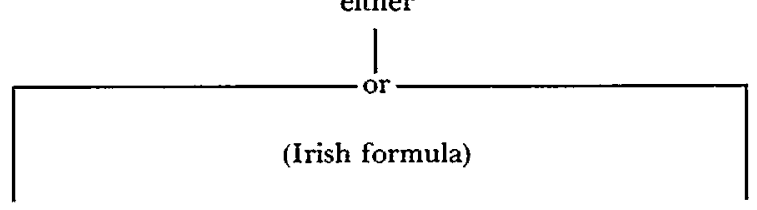

where thickness of sedimentary not more than 60 miles rocks is at least $1 \%$ of distance beyond foot of continental beyond foot of continental slope

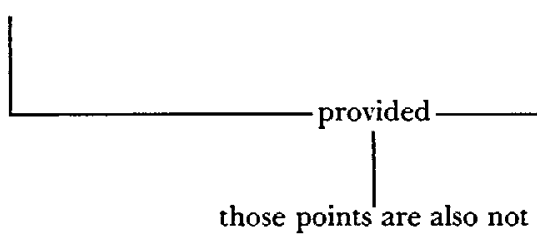
beyond further seaward of

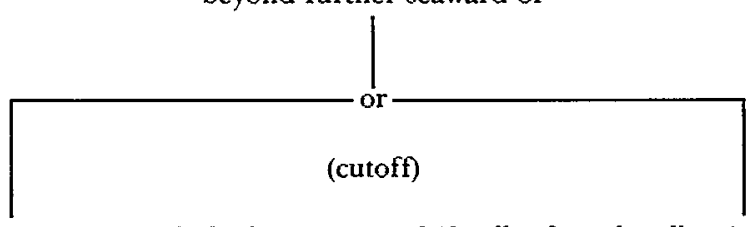

100 miles beyond 2500 -meter isobath 350 miles from baseline (coast)

only the 350-mile cutoff may be applied on submarine ridges if those ridges are not submarine elevations that are natural components of continental margin such as its plateaux, rises, caps, banks and spurs 
Limits of the Continental Shelf will apply the consensus statement along with Article 76.

(3) The composition, functions, and procedures of the proposed Ciommission on the Limits of the Continental Shelf, including the arrangements in the evient the coastal state has difficulty accepting the Commission's initial reactions to coastal state charts. As a result of negotiations during the first part of the ninth session, there is a new annex on the Commission on the Limits of the Continental Shelf ${ }^{00}$ and a corrected text dealing with the effect of the Commission's recommendations. ${ }^{91}$

The Commission is elected by the parties to the Convention. It consists of 21 "experts in the field of geology, geophysics or hydrography . . . who shall serve in their personal capacities." ${ }^{\text {2 }}$

A coastal state desiring to establish the limits of its continental shelf seaward of 200 miles "shall submit particulars of such boundary to the Commission along with supporting scientific and technical data as soon as possible but in any case within 10 years of the entry into force of this Convention for that State." ${ }^{93}$ The Commission's recommendations on the submission are prepared by a seven-member subcommission and approved by a two-thirds majority of Commission members present and voting. ${ }^{94}$

At this point, the coastal state may agree or disagree with the recommendations. If it agrees, the coastal state is given an extraordinary power nowhere reproduced with respect to any other maritime limit: the continental shelf limits "established by a coastal State on the basis of these recommendations shall be final and binding." 95 They may not be contested. The coastal state then deposits with the UN Secretary-General the relevant charts and data "permanently" describing the outer limits of its continental shelf both at and beyond 200 miles. ${ }^{96}$

These texts give effect to an important recommendation of the Marine Science Commission established by the U.S. Congress at the very start of the current efforts: namely, that given the need for certainty by miners on both sides of the line in order to promote development of resources, provision should be made for the establishment of a line that will not be changed. ${ }^{97}$

"In the case of disagreement by the coastal State with the recommendations of the Commission, the coastal State shall, within a reasonable time, make a revised or new submission to the Commission." state that disagrees with the Commission is denied the extraorclinary power to insist that all other parties to the Convention are bound to accept its views regarding the proper application of Article 76, it is not denied the right to reject the Commission's approach. The Commission is not a court,

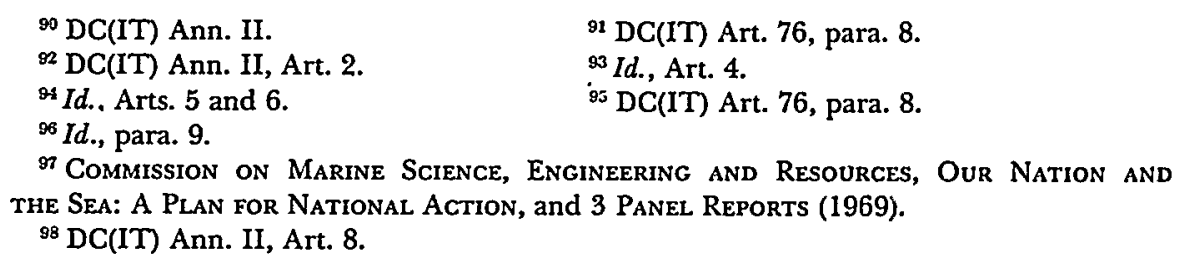


and legal expertise is not included among the express qualifications of its members. ${ }^{99}$

It is assumed that, in practice, both the coastal state and the subcommission will do their best to ensure that the Commission will not approve even initial recommendations that are likely to be rejected by the coastal state. ${ }^{100}$ This was considered one of the advantages of using noncontentious ex parte review by an international commission of experts independent of the SeaBed Authority.

(4) The exemption of developing coastal state importers from the obligation to contribute revenues derived from mineral exploitation of the continental shelf beyond 200 miles. While there was growing support among developing country delegations for making a change in the exemption, so much time was devoted to other, more critical aspects of the continental shelf problem thatshort of the extreme and unreasonable step of jeopardizing the whole settlement on the continental margin because of the exemption issue-there was no opportunity to achieve the necessary measure of support for a change. ${ }^{101}$

\section{Delimitation of the Economic Zone and Continental Shelf Between States with Opposite or Adjacent Coasts}

(1) The substantive principles governing delimitation, including related matters such as the right of a state to fle a definitive declaration of interpretation of these principles. At the end of the first part of the ninth session, the Chairman of Negotiating Group 7 submitted a proposed new text on delimitation to the Plenary, which was greeted with cries of anguish from the most vocal advocates of the two opposing points of view. The text changed the words of the ICNT. What else it changed is a matter upon which even the most courageous may hesitate to speculate. The respective texts of paragraph 1 of Article 74 are shown in table 1.

Some supporters of greater emphasis on equitable principles sent a strongly worded letter to the President of the conference objecting to the incorporation of the revised text into the ICNT/Rev.2 since the plenary debate did not, in their view, indicate that this text had "widespread and substantial support." 102 The difficulty of applying the latter standard is that no proposal on this subject is likely (at least before "one minute to midnight") to enjoy such support in a debate on the record when many delegations are preoccupied with domestic reactions, political signals to their

\footnotetext{
Id., Art. 2.

Iow If requested, the Commission may aid the coastal state in preparing its data for submission. $I d$., Art. 3(b). In any event, a representative of the coastal state making the submission may participate in relevant proceedings without the right to vote. Id., Art. 5 .

${ }^{101}$ See $74 \mathrm{AJIL}$ at 23 for a discussion of the problem and the alternative proposal by the U.S. delegation. See also note 18 supra.

1"12 The President's explanatory memorandum to the ICNT/Rev.2, paragraph 10 states that the Chairman of the Second Committee expressed reservations regarding the incorporation of the new provisions into the ICNT/Rev.2.
} 
TABLE 1

TEXTS OF ARTICLE 74(1)

\begin{tabular}{ll}
\hline \multicolumn{1}{c}{ ICNT/Rev.1 } & \multicolumn{1}{c}{ ICNT/Rev.2 and DC(IT) } \\
\hline $\begin{array}{l}\text { The delimitation of the exclusive economic } \\
\text { zone* between adjacent or opposite States } \\
\text { shall be effected by agreement in accordance } \\
\text { with equitable principles, employing, where }\end{array}$ & $\begin{array}{l}\text { The delimitation of the exclusive economic } \\
\text { zone* between States with opposite or } \\
\text { appropriate, the median or equidistance } \\
\text { ment in conformits be effected by agree- } \\
\text { cine, and taking account of all the relevant } \\
\text { circumstances. }\end{array}$ \\
$\begin{array}{l}\text { Such an agreement shall be in accordance } \\
\text { with equitable principles, employing the } \\
\text { median or equidistance line, where } \\
\text { appropriate, and taking account of all } \\
\text { circumstances prevailing in the area } \\
\text { concerned. }\end{array}$ \\
\hline
\end{tabular}

* Article 83, paragraph 1 uses the same text in connection with the continental shelf.

neighbors, and genuine concern that their open support would induce opposition from someone else. ${ }^{103}$

At the resumed session, the two groups concerned negotiated directly in an intensive series of meetings. While there was insufficient time to complete the work, it does seem possible that agreement might be reached on a few wording changes. The discussion also revealed that the proposal already worked out at the eighth session on interim measures ${ }^{104}$ enjoyed general support.

In some respects, the most interesting developments occurred in the discussions regarding reservations in the Informal Plenary on Final Clauses. It was possible to achieve agreement on an article prohibiting reservations "unless expressly permitted by other articles of this Convention" only by attaching a footnote that states in pertinent part that "the article can be regarded only as provisional pending the conclusion of discussions on outstanding substantive issues such as that relating to the delimitation of maritime zones as between adjacent and opposite States and to settlement of disputes thereon, where the final solution might include provision for reservations." 105

Moreover, the discussions on reservations revealed another aspect of the problem: the relationship between Articles 74 and 83 on delirnitation and Article 121 on the regime of islands. Some are worried by the implications for delimitation of the rule that islands are treated in the same way as other land territory. ${ }^{106}$ Others are worried by the exception to this rule, "Rocks which cannot sustain human habitation or economic life of their own shall have no exclusive economic zone or continental shelf." 107 In fact, both sides may be seeking assurance that a reservation to Articles 74 and 83 constitutes

${ }^{103}$ The criteria for incorporation of a revised text set forth in Doc. A/CONJ.62/62 are discussed by the author in 73 AJIL at 4-5 and 74 AJIL at 2 .

${ }^{104}$ ICNT/Rev.2 and DC(IT) Art. 74, para. 3, and Art. 83, para. 3. See 74 AJIL at 5.

${ }_{105} \mathrm{DC}$ (IT) Art. 309 and n.1.

${ }^{108}$ DC(IT) Art. 121, para. 2.

${ }^{102} I d$. , para. 3. 
a reservation to Article 121 , insofar as the latter is relevant to the two articles on delimitation. Such a reservation would not, of course, affect the application of Article 121 to determining the seaward limits of coastal state jurisdiction where delimitation between states with opposite or adjacent coasts is not the issue.

(2) The scope of the compulsory conciliation of delimitation disputes. The proposal of the Chairman of Negotiating Group 7 regarding settlement of delimitation disputes was incorporated into the ICNT/Rev.2 and, tactics aside, was not the subject of much subsequent concern.

The text ${ }^{108}$ permits a state to refuse to accept compulsory third-party arbitration or adjudication regarding delimitation between states with opposite or adjacent coasts. However, it must accept submission to nonbinding conciliation when the dispute "arises subsequent to the entry into force of" the Convention and "where no agreement within a reasonable period of time is reached in negotiations between the parties," with the exception of a "dispute that necessarily involves the concurrent consideration of any unsettled dispute concerning sovereignty or other rights over continental or insular land territory." 109

\section{Marine Mammals}

The revised text on marine mammals long sought by various environmental groups and strongly supported by the U.S. delegation was finally approved with minor revisions by the Second Committee at the first part of the session. ${ }^{10}$ The text makes clear that it permits either a complete prohibition or more restrictive limitations or regulations to protect marine mammals than the Convention would otherwise require and directs particular attention to the need for appropriate organizational arrangements for the protection of whales and other cetaceans. Thus, once this Convention enters into force, it will definitively overrule arguments made by some whalers and sealers that protective measures for marine mammals can do no more than ensure the maintenance of a maximum sustainable yield, and that international regulation of whales and other cetaceans can be approached in the same way as such regulation is pursued in the case of ordinary commercial fisheries. The Convention would therefore remove legal roadblocks and open the substantive and procedural doors to the type of strong and effective protection of marine mammals that is being urged by environmentalists and conservationists of many nations.

\footnotetext{
IUs ICNT/Rev.2 and DC(IT) Art. 298, para. I(a).

${ }^{\text {xvy }} \mathrm{Ibid}$. While the exclusion for land territory disputes is drafted so that it does not literally apply to adjudication or arbitration under the Convention when a state does not elect to reject such procedures, it would seem that this is a mere drafting point. In any event, the same result seems implicit in the fact that the jurisdiction of a judicial or arbitral tribunal under the Convention is limited to the interpretation or application of the Convention. The Convention does not deal with questions of sovereignty or other rights over continental or insular land territory - questions that can hardly be regarded as incidental or ancillary.

"11" DC(IT) Art. 65 is the same as the draft text in 74 AJIL at $5 \mathrm{n} .23$ except that the words, "In this connexion," have been deleted from the start of the second sentence.
} 


\section{Other Second Committee Matters}

At the first part of the ninth session, the Second Committee completed a full review of all proposals for changes outside the mandate of the various negotiating groups. In addition to the amendment on marine mammals, it approved the technical amendments on suspension of innocent passage already negotiated at the eighth session ${ }^{111}$ and a few other technical proposals. Controversial suggestions regarding archaeological and historical objects $^{112}$ and the use or threat of force were ultimately dealt with during the resumed ninth session by the Informal Plenary on General Provisions, and will be discussed by the author in that context.

During the resumed ninth session, the Second Committee reviewed various recommendations of the Drafting Committee, but discussed only those that might have some substantive implications. It supported most of the Drafting Committee's suggestions.

Extensive discussion between some straits states and maritime countries resulted in a few nonsubstantive technical clarifications that could command consensus and substantially reduce the concerns of straits states about the straits articles. Aside from a new general provision, ${ }^{113}$ all were clearly of a technical character designed to elucidate the interpretation of the existing text. While there were no objections to their substance, the texts never made it all the way through some complex procedures and presumably will be considered again at the next session.114

The Argentine and Canadian delegations tried to increase the rights of the coastal state regarding fish stocks found both within and in areas immediately seaward of the economic zone. ${ }^{115}$ They were opposed by other

111 DC(IT) Art. 25, para. 3 adds the words "including weapons exercises." See 74 AJIL at 4-5 and n.22.

${ }^{112}$ Conf. Doc. C.2/Informal Meeting/43/Rev.I (1979). See 74 AJIL at 23 n.79.

113 Discussed infra at p. 242.

114 The proposed amendments are as follows.

Article 42(1)(b): change "applicable" to "generally accepted" international regulations (as, for example, in Art. 39(2)(b)). The English Language Group of the Drafting Committee has already included this in its recommendation on harmonization of these terms in various articles. Conf. Doc. ELGDC/4 (1980).

Article 42(1)(b): delete the word "oily" in the phrase "oil, oily wastes and other noxious substances."

Article 221: make clear that the international law right of intervention following upon a maritime casualty is preserved not only beyond the territorial sea but within the territorial sea in straits. The main problem here was to find a way to draft around the position of a few coastal states that the right of intervention is inherent in their sovereignty in the territorial sea, and thus ought not to be mentioned in connection with a provision dealing with other areas.

Article 233: make clear that the exclusion of sections 5, 6, and 7 of the pollution text from application to "the legal regime of straits used for international navigation" refers to passage, not to activities other than passage, which would conform it to the general principle stated in Article 34, paragraph 1 and the rule in Article 38, paragraph 3.

${ }^{115}$ See DC(IT) Art. 63, para. 2. 
delegations both on the merits and because of a general reluctance to reopen fisheries questions. ${ }^{116}$

The major unsettling factor in the work of the Second Committee is the effort of some delegations to promote an amendment requiring prior notification to and authorization by the coastal state for innocent passage of warships through the territorial sea. Such an amendment cannot command consensus.

This effort is part of a still broader problem. Since so many of the sensitive issues in the Second Committee were resolved many years ago, it is not as apparent to some in that committee as it is, for example, in the First Committee that artificial voting victories by numerical majorities would be purely pyrrhic - there would be no ratified Convention, and no evidence of acceptance of the preferred text by those most affected for purposes of customary law. Even if it were assumed that the substantive impact on major maritime countries of an adverse vote on a particular issue might not alone be sufficient to destroy any chance that they would accept the Convention, it would almost certainly have that effect when coupled with anger at the vote itself and other reasons for being ill at ease with the Convention.

\section{The Third Committee}

Despite assumptions that informal substantive negotiations on marine scientific research had been completed at the eighth session, ${ }^{117}$ there was a concerted effort by some coastal states to alter the accommodations made. The result of intensive negotiation and debate during the first part of the ninth session was agreement on some changes in the precise phraseology proposed by the Chairman of the Third Committee in his report ${ }^{118}$ at the end of the eighth session. The substance of those recommendations, however, was preserved.

The greatest difficulty involved the precise words to describe those areas of the continental shelf beyond 200 miles designated by the coastal state in which it has the right to exercise its discretion to withhold consent for marine scientific research. Under the Chairman's proposal, the coastal state could designate "areas in which exploitation or exploratory operations, such as exploratory drilling are occurring or are about to occur." 119 The new text expresses the same thought in a different way by referring to designation of areas "in which exploitation or detailed exploratory operations focused on those areas are occurring or will occur within a reasonable period of time." 120

The decision by the coastal state to exercise its discretion to designate

11' A compromise effort to redraft Article 63, paragraph 2 to bring it into closer conformity with Article 117 (which applies to all conservation problems beyond the economic zone) encountered belated opposition, but may be considered again.

${ }^{117}$ See $74 \mathrm{AJIL}$ at $24-29$.

${ }^{11}$ UN Doc. A/CONF.62/91, at 75 (1979), setting forth UN Doc. A/CONF.62/L.41 (1979).

${ }^{114}$ Id., Art. 24b bis. ${ }^{120} \mathrm{DC}(\mathrm{IT})$ Art. 246 , para. 6. 
such areas and to withhold consent for one of the enumerated reasons is not itself subject to third-party settlement. ${ }^{121}$ However, the questions whether it has discretion and whether that discretion is being exercised in a manner compatible with the Convention are not thereby excluded. Specific provision is made for compulsory conciliation in this connection. ${ }^{122}$

Not until the ninth session was it possible to distinguish rationally between "suspension" and "cessation" of research activities. It has now been made clear that the coastal state may require cessation immediately in case of a "major change" in the project or activities as compared with the description on which the coastal state based its consent. In other cases, it may request compliance or, if need be, order suspension; if the violations "are not rectified within a reasonable period of time," it may then require cessation of the project. ${ }^{123}$ The order of suspension must be lifted as soon as the researching state has rectified the delinquencies that caused suspension to be invoked. The decision to order suspension or cessation is subject to compulsory conciliation regarding compatibility with the Convention. ${ }^{\mathbf{1 2 4}}$

One unfortunate change in the text is the restriction on presumed consent for international organizations of which the coastal state is a member to carry out projects earlier approved by that state in detail within the organization. ${ }^{125}$ This presumption could have helped to encourage tangible aid and support for regional scientific research organizations of developing countries from countries with substantial oceanographic capabilities. The presumption was qualified by a French amendment that allows the coastal state to object within 4 months of notification of the project by the organization. ${ }^{126}$ The change seems to reflect concern by foreign ministries that governments may not have, or ought not to be encouraged to seek, tight political control over their delegations' participation in the project decisions of intergovernmental scientific organizations. The result is only somewhat better than the result that would obtain under the general provision for implied consent when the coastal state does not respond within 4 months. ${ }^{127}$ Nevertheless, the rule of implied consent is itself a significant benefit of the Convention.

Informal negotiations on marine scientific research, and with them the informal negotiations of the Third Committee, were completed at the end of

${ }^{21}$ DC(IT) Art. 297, para. 2(a).

${ }^{122} I d$., para. 2(b). Furthermore, the text makes clear that the phrase "in normal circumstances" refers to the state of relations between the researching state and the coastal state by adding language stating that the absence of diplomatic relations between them does not necessarily mean that circumstances are not normal. A crucial change was made in paragraph 2 of Article 249, which now states that (1) only with respect to those research activities specified in paragraph 5 of Article 246 may the coastal states impose obligations additional to those contained in its paragraph 1 ; and (2) limitations on international release of research findings apply only to results of direct significance for exploration and exploitation and these limitations must be reasonable. Finally, the broadly stated obligation in Article 249 to assist coastal states in assessing research results has been appropriately clarified by allowing a choice of methods. This would be a one-time obligation for each research project, not a continuing one.

${ }^{123} \mathrm{DC}(\mathrm{IT})$ Art. 253.

${ }^{125}$ See ICNT/Rev.1 Art. 247.

${ }^{124} \mathrm{DC}(\mathrm{IT})$ Art. 297, para. 2.

${ }^{127}$ Id., Art. 252.

${ }^{126}$ See DC(IT) Art. 247. 
the first part of the ninth session. During the second part of the session, the Third Committee met several times to consider a list of drafting changes proposed by the Chairman, some of which drew upon the recommendations of the Drafting Committee. The procedure followed, by which a change would not be made if a delegation maintained its objections, enabled the Third Committee to function in a reasonably relaxed fashion without fearing that it was opening the door to substantive negotiations that could alter the balance of the text. However, Article 208, paragraph 3 is still incorrectly drafted.

The procedural approach to determining whether a particular change alters the substantive balance of the text may be preferable to attempts to draw the line between substance and drafting in principle. The underlying idea is that if a delegation persists in maintaining that a particular change would adversely alter the substantive balance, after reasonable efforts to persuade it otherwise, then that change ought not to be treated as a technical or drafting matter.

\section{The General Provisions}

Part XVI of the text contains five new "general provisions" prepared in the Informal Plenary. The first three were presented as a compromise package negotiated by various supporters and opponents of the original proposals.

\section{Good Faith and Abuse of Rights}

The first article ${ }^{128}$ obligates the parties to "exercise the rights, jurisdictions and freedoms recognized in this Convention in a manner which would not constitute an abuse of rights." The article reflects an idea originally presented by Mexico and, as redrafted, cosponsored by the U.S. delegation. ${ }^{129}$

\section{Peaceful Uses of the Seas}

Another new article, ${ }^{130}$ inspired by Article 2, paragraph 4 of the UN Charter, requires states parties, in exercising their rights under the Conven-

${ }^{12 \mathrm{M}} \mathrm{DC}($ IT) Art. 300.

12:4 Conf. Doc. GP/2 and Rev.1 (1980).

An innocuous reference to "all relevant circumstances," which surely have to be considered in determining the existence of abuse, nevertheless had to be removed because of objections from delegations that prefer to emphasize equidistance rather than relevant circumstances in the Convention's articles on delimitation of the economic zone or continental shelf between states with opposite or adjacent coasts. There was an air of arrière pensée in this skirmish, perhaps related to the possibility that in the end the Convention may contain no articles at all on delimitation between neighboring states, or that reservations will be permitted to those articles.

Article 300 contains a slight drafting problem that arose in repeated translation between Spanish and English. It requires good faith discharge of obligations entered into "in conformity with this Convention." That language is intended to refer to obligations under the Convention itself.

${ }^{* 30}$ DC(IT) Art. 301. 
tion, to "refrain from any threat or use of force against the territorial integrity or political independence of any State, or $^{\mathbf{1 3 1}}$ in any other manner inconsistent with the principles of international law embodied in the Charter of the United Nations."

A similar obligation already applied under the ICNT to the flag state or state of registry of ships and aircraft exercising the right of transit passage through straits or the right of archipelagic sea lanes passage. ${ }^{132}$ Moreover, such a threat or use of force is expressly incompatible with innocent passage. ${ }^{133}$ In addition, the ICNT contained express requirements regarding uses for "peaceful purposes" applicable to the economic zone and the high seas, ${ }^{134}$ as well as to the deep seabeds. ${ }^{135}$

The proponents of the clause on force wanted it added to the articles on the exclusive economic zone, using language identical to that of the Charter. This was rejected by the maritime states. They noted the problems of selective quotation from the Charter out of context, and the inappropriateness of including an article on security questions in the regime of the economic zone.

Each side was able to argue that the other was being unreasonable since the obligation contained in the UN Charter is binding on all in any event. There was very broad support during the debate for including a general clause on the subject. To accommodate the objections, the resulting provision, like the ICNT texts from which it was drawn, repeats the Charter requirements without creating new rights or obligations: it cross-references all of the principles of international law embodied in the Charter and applies to all states, whether coastal or flag states, with respect to all parts of the sea. ${ }^{136}$

\section{Disclosure of Information}

Another new provision, originally proposed by the United States ${ }^{137}$ and inspired by the Treaty of Rome, ${ }^{138}$ makes clear that a state party is not required "to supply information the disclosure of which is contrary to the

\footnotetext{
131 The President was not successful in his attempt to persuade the conference to insert the word "act" here in order to correct what he felt was an error in the wording of the Charter itself.

${ }^{132}$ ICNT/Rev.1 and DC(IT) Arts. 39, para. 1(b) and 54.

${ }^{133}$ ICNT/Rev.1 and DC(IT) Art. 19, para. 2(a).

${ }^{134}$ ICNT/Rev. 1 and DC(IT) Arts. 58, para. 2 and 88.

${ }^{135}$ ICNT/Rev.1 and DC(IT) Art. 141.

${ }^{136}$ In light of the general application of the new clause to the overall behavior of states at sea, it was considered more appropriate to use the Charter word "inconsistent" (with the principles of international law embodied in the Charter) than the term "in violation" (of those principles) which is used in the specific operational context of particular ships in innocent passage or particular ships or aircraft in transit passage or archipelagic sea lanes passage. Compare DC(IT) Arts. 19, para. 2(a) and 39, para. 1(b) with Art. 301.

${ }^{137}$ Conf. Doc. GP/3 (1980).

${ }^{238}$ Treaty Establișhing the European Economic Community, in force Jan. 1, 1'958, 298 UNTS II, Art. 223, para. 1(a).
} 
essential interests of its security." ${ }^{139}$ There was very broad support from all regions and groups for the principle involved, and no dissent. The difficulties lay in finding a text that did not create an unintended potential for bad faith and abuse, particularly with respect to transfer of technology obligations, and in overcoming objections to copying a text from another treaty with limited participation and authoritative interpretive mechanisms of its own.

There are three elements to the solution. First, a state enjoys the right to withhold security information "in the fulfilment of its obligations under the relevant provisions of the Convention." This clause emphasizes the limited purposes of the exclusion: on the one hand, the obligations cannot be applied to require or coerce the disclosure of essential security information; on the other hand, the right to withhold such information does not in other respects alter the duty to fulfill obligations under the Convention.

Second, the exclusion is "[w]ithout prejudice to the right of any State Party to resort to the procedures for the settlement of disputes" provided in the Convention. This clause was understood to incorporate the widely followed national practice pursuant to which, if a government chooses not to contest a particular case or issue rather than reveal the information necessary to do so, it cannot require that the case be dismissed or the issue decided in its favor merely because it has a right to withhold information necessary to proper adjudication. ${ }^{140}$

Third, it is made clear that the exclusion cannot be abused, and that the state concerned must be acting in good faith. This was achieved by presenting the article as part of a package that includes the article prohibiting abuse of rights, and by excluding the words "it considers" before the words "contrary to the essential interests of its security."141

\section{Archaeological Objects Found at Sea}

There has long been general agreement on a provision dealing with "archaeological and historical objects" found on the deep seabeds. ${ }^{142}$

13: DC(IT) Art. 302.

14 Preservation of the right to "resort to" dispute settlement procedures specifically refers to a jurisdictional issue such as might arise under one of the optional exceptions to third-party settlement in DC(IT) Art. 298. These words limit the application of this "no prejudice" clause to the right to bring the action. The "no prejudice" clause does not apply to the gathering of evidence in the exercise of that right; one of the reasons for the article is to protect a state from any requirement to produce security information in evidence.

141 Developing country jurists, of course, were quick to point out that these textual safeguards did not and logically could not have the effect of requiring or coercing a state to reveal secret information to foreign nationals or others in order to show its good faith, or of punishing it for failure to do so. They nevertheless felt that the result was an important political restraint on abuse, in particular in applying the exclusion to the obligation to transfer deep seabed mining technology. The President was referring to this good faith requirement in his report when he said that the exclusion does not detract from the transfer of technology obligations. UN Doc. A/CONF.62/L.58 (1980).

${ }^{142}$ Art. 149 of the $\mathrm{DC}(\mathrm{IT})$ and its predecessor texts. 
The lack of controversy was doubtless due, at least in part, to the relatively slight concern that many such objects would be found in areas seaward of the 200-mile economic zone and the continental margin. ${ }^{143}$

The real focus of concern is the area immediately adjacent to the territorial sea, particularly in the Mediterranean Sea. Proposals were made to give the coastal state a new right over its continental shelf, namely, the control of archaeological objects. ${ }^{144}$ These were found objectionable on substantive grounds and because they would reopen negotiations on the substance of the economic zone and continental shelf regimes. Major maritime powers made clear that they could not accept a general extension to the continental shelf or economic zone of a set of coastal state rights that bore no relation to natural resources. They argued that over time it could alter the conceptual character of the regimes applicable to those areas, a matter of particular importance in dealing properly with the question of allocating residual rights. The U.S. delegation proposed a new general provision on the subject that introduced for the first time the idea of a duty to protect archaeological objects found at sea. ${ }^{145}$ This proposal was regarded as helpful but inadequate because it failed to provide for enforcement with respect to many small craft beyond effective flag state supervision. Cn the other hand, while enforcement protection in the territorial sea alone was insufficient, ${ }^{146}$ the vast seaward reaches of the economic zone and continental shelf were really not relevant to the problem. The main issue was the policing of the area immediately beyond the territorial sea.

The 24-mile contiguous zon $\mathrm{e}^{147}$ virtually suggested itself. No one objected to the result of yielding some enforcement powers over archacological objects in the area to the coastal state, provided they were narrowly circumscribed and did not constitute a precedent.

Nevertheless, this solution posed a jurisprudential problem. ${ }^{148}$ To create a new "archaeological" zone, or expressly to expand the competence of the coastal state to include regulation of diving for archaeological objects in the contiguous zone, would amount to converting the contiguous zone from an area where the coastal state has limited enforcement competence to one where it has legislative competence. ${ }^{149}$

${ }^{43}$ Even so, Article 149 reveals that the "internationalists" obtained a reference to the "benefit of mankind as a whole" but no role for the Sea-Bed Authority, while the various "States of origin" obtained an exhortation that "particular regard" be paid to their "prejerential rights" but that fell short of confirming any particular right or proprietary interest.

${ }^{144}$ See note 112 supra. ${ }^{145}$ Conf. Doc. GP/4 (1980).

${ }^{146}$ Particularly for a state that might not extend its territorial sea to 12 miles.

${ }^{147}$ Art. 33 of the $\mathrm{DC}(\mathrm{IT})$ and its antecedents.

${ }^{148}$ The rights of the coastal state in the contiguous zone do not apply as such to archaeological objects found there. These rights are limited to exercising the control in the zone necessary to prevent and punish infringement within its territory or territorial sea of its customs, fiscal, immigration, or sanitary regulations. Ibid.

${ }^{149}$ There would then arguably be less doctrinal basis for preventing a gradual expansion of the legislative competences of the coastal state in the zone with respect to matters not included within its economic zone and continental shelf rights, and thus inevitably in the direction of a territorial sea. 
Faced with such problems, judges and legislators have since time immemorial (or, more appropriately in this case, at least since the days of ancient Rome) taken refuge in the minor premise: presume the facts and leave the principle intact. Certainly, in many cases the small craft engaged in recovering archaeological objects immediately beyond the territorial sea of a coastal state are operating out of a port or anchorage of that state. Accordingly, a basis exists in fact for the creation of a presumption that removal of an archaeological object from the seabed within the contiguous zone would result in an infringement within its territory or territorial sea of the customs, fiscal, immigration, or sanitary regulations of the coastal state. Although in some cases this is a legal fiction, it serves some of the timehonored functions of legal fictions: it avoids the procedural and substantive risks and complications of a doctrinal change and in a special situation achieves with efficiency a generally desired result. ${ }^{150}$

The resultant article ${ }^{151}$ establishes a basic duty of states to protect archaeological objects and objects of historical origin ${ }^{152}$ found at sea and to cooperate for this purpose. It sets forth the presumption regarding their removal from the seabed of the 24-mile contiguous zone. It contains a disclaimer of any effect on private law or rights, that is, "the rights of identifiable owners, the law of salvage or other rules of admiralty, or laws and practices with respect to cultural exchanges." 153

${ }^{150}$ L. Fuller, Legal Fictions (1967), contains a classic analysis of the subject of legal fictions that was being read at the time this conceit was formed. Appearing as it does in a public law convention of organic character, the conceit ought (for better or worse) to be treated as a true fiction - a rule of law-rather than as a rule of evidence.

${ }^{15 x}$ DC(IT) Art. 303.

${ }^{152}$ The term "archaeological objects and objects of historical origin" is not defined. It is a ruformulation of the term "objects of an archaeological and historical nature" that appears in the deep seabed mining text (Art. 149).

The provision is not intended to apply to modern objects whatever their historical interest. Retentron of the adjective "historical" was insisted upon by Tunisian delegates, who felt that it was necessary to cover Byzantine relics that might be excluded by some interpretations of the word "archaeological." Hence, the term historical "origin," lacking at best in elegance, when used with the term "archaeological objects" in an article that expressly does not affect the law of salvage, does at least suggest the idea of objects that are many hundreds of years old.

The article contains no express time limit. As time marches on, so does our sense of what is old. Nevertheless, given the purpose for using the term "historical," it may be that if a rule of thumb is useful for deciding what is unquestionably covered by this article, the most appropriate of the years conventionally chosen to represent the start of the modern era would be 1453: the fall of Constantinople and the final collapse of the remnants of the Byzantine Empire. Everything older would clearly be regarded as archaeological or historical. A slight adjustment to 1492 for applying the article to objects indigenous to the Americas, extended perhaps to the fall of Tenochtitlán (1521) or Cuzco (1533) in those areas, might have the merit of conforming to historical and cultural classifications in that part of the world.

15* There is no reference to disposal, and accordingly no reference either to the benefit of mankind or to the rights of various states of origin as in Article 149. Recognizing that a convention on the law of the sea can deal with only a small part of the broader issue of protection and disposal of archaeological objects, Article 303 "is without prejudice to other international agreements and rules of international law regarding the protection of archaeological objects and objects of historical origin." 


\section{Responsibility and Liability for Damage}

A further general clause makes clear that the liability and responsibility provisions of the Convention "are without prejudice to the application of existing rules and the development of further rules regarding responsibility and liability under international law." This clause was designed to allay the concerns of Spain and Morocco that because Article 42 provides for responsibility of the flag state only in cases of violation of the straits articles themselves (and specific regulations referred to in that article), I he Convention might be construed, albeit improperly, in a manner that excludes liability or responsibility under international law for damages caused by acts of a government ship or state aircraft that are not violations of the straits articles. $^{154}$

\section{SetTlement of Disputes}

Most of the work regarding settlement of disputes at the ninth session was done in connection with the various substantive negotiations: First Committee matters by the Group of Legal Experts on Settlement of Disputes, settlement of delimitation disputes by Negotiating Group 7, and disputes over marine scientific research by the Third Committee. These have already been discussed.

In addition to this work, the Informal Plenary on Settlement of Disputes considered a variety of proposals, most of them technical and organizational in character. The most important result was a reorganization that clarifies the structure of part XV by dividing it into three sections.

The first section sets forth the general obligation to settle disputes peacefully and deals with the relationship between the dispute settlement procedures of the Convention and those contained in other agreements.

Section 2 sets forth the compulsory procedures entailing a binding decision under the Law of the Sea Convention. It establishes the obligation to submit to binding adjudication or arbitration disputes regarding the interpretation or application of the Convention at the request of any party to the dispute. ${ }^{155}$

Section 3 sets forth limitations and optional exceptions to the obligation to adjudicate or arbitrate under section 2. It establishes an alternative obligation to submit some disputes excepted from adjudication or arbitration to nonbinding conciliation at the request of any party to the dispute. Annex $\mathrm{V}$ on conciliation procedures was revised to take account of the possibility that conciliation proceedings in such cases might be instituted at the request of only one party and without the cooperation of the other in appointing conciliators.

\footnotetext{
${ }^{154}$ Spain and Morocco are correct that this would be a misinterpretation. The function of the responsibility provision in the straits articles is to make clear that no enforcement action may be taken against a ship or aircraft entitled to sovereign immunity, and that the appropriate remedy lies in the international responsibility of the flag state. DC(IT) Art. 42, para. 5; accord Art. 233.
}

155 DC(IT) Art. 286. 
Negotiations regarding settlement of disputes can now be regarded as completed. (A few minor drafting and technical problems remain, which can easily be resolved in due course. ${ }^{156}$ ) The importance of this unprecedented achievement in a major global convention cannot be emphasized too strongly. Any assessment of the benefits and costs of the Convention will have to give considerable weight to the dispute settlement provisions. They serve not only the particular interests protected, ${ }^{157}$ but also much broader interests in extending the rule of law and resort to third-party procedures for resolving differences as an alternative both to conflict and to excessive centralized regulation.

\section{The Final Glauses}

Aside from the work on the problems regarding deep seabed mining, the most intensive and productive work of the ninth session was devoted to the final clauses. This included an instructive, informal intersessional meeting of active participants in the Group of Legal Experts on Final Clauses in late autumn of 1979; intensive work in the group during the first part of the ninth session, which resulted in the final report of its Chairman; ${ }^{158}$ and detailed review and negotiation in the Informal Plenary on Final Clauses during a resumed session, which culminated in the final clauses recommended by the President and incorporated into the new text. ${ }^{159}$

\section{Eutry into Force and the Preparatory Commission}

The Convention provides that it is subject to ratification. ${ }^{160}$ One question posed was how many instruments of ratification need to be deposited before the Convention can enter into force for those states that have ratified it. The conflicting objectives at stake included, on the one hand, a desire to see the Convention enter into force as soon as possible and, on the other, a desire to ensure broadly' representative participation. The compromise reached on

\footnotetext{
17. Among these is the question of using ad hoc chambers of the Sea-Bed Disputes Chamber in cases involsing the Authority. The Group of Legal Experts on Settlement of Disputes concernung First Committee matters was unable to finish this work because of the press of other First Committee business.

In light of points raised by the Argentine and Canadian delegations regarding fisheries beyond the exclusive economic zone, there may be a desire to emphasize on the record that the power of a court under Article 290 to prescribe provisional measures pending final adjudication in order "to preserve the respective rights of the parties to the dispute or to prevent serious harm to the marine environment" includes the power to order provisional conservation measures to protect the fish stocks. In this connection, it should be noted that the Charman of the Third Committee has already reported a consensus that the term "marine environment" uncludes marine life. 10 OFF. REc. 97 (1978). It might also be noted that there is precedent for such action in the Icelandic Fisheries Jurisdiction case, [1974] ICJ REP. 3.

${ }^{17}$ Ranging from the right to obtain prompt release of a seized oil tanker without awaiting cxhaustuon of local remedies (Art. 292) to the right to ensure compliance with environmental standards (Art. 297, para. 1(c)).

15x Conf. Doc. FC/20 (1980). $\quad{ }^{159}$ DC(IT) pt. XVII.

an' DC(IT) Art. 306. In this discussion references to ratification include accession.
} 
a requirement of 60 ratifications is, by its nature, artificial: it can as easily frustrate as promote either objective. ${ }^{161}$

The more difficult problems concerned the relationship between the entry into force of the Convention and the establishment of the deep seabed regime and machinery. It has been asserted for many years that the deep seabed regime is an integral part of any "package deal" for a substantial number of developing countries. It follows that the regime must be operational when the Convention enters into. force. Otherwise, its prohibition on any claim, acquisition, or exercise of mineral rights and on alienation of minerals except in accordance with the Convention and the rules and regulations adopted thereunder ${ }^{162}$ could be construed to effect a total prohibition on all deep seabed mining. Industrial and consumer nations could hardly be expected to accept such a result.

The Authority is required to take up for consideration proposed plans of work (mining contracts) and applications for production authorization 6 months after the entry into force of the Convention. ${ }^{163}$ In order for those proposed plans of work to be prepared properly and evaluated, all of the rules, regulations, and procedures regarding deep seabed mining must be in place, at least provisionally. In addition, the organs of the Authority must be established and able to execute their functions with respect to deep seabed mining.

It was generally agreed that a Preparatory Commission should be established to draft rules, regulations, and procedures and to make other preparations to enable the Authority to function when the Convention enters into force. Considerable progress was made during the first part of the session on a conference resolution to establish such a Commission. ${ }^{104}$ Of the remaining issues to be dealt with in the resolution, perhaps the most interesting is whether states that do not signify a positive interest in becoming party to the Convention by signing it will be permitted to attend meetings, not merely perhaps as observers, but as full members of the Commission.

The legal arrangements attendant upon entry into force of the Convention are dealt with in the Convention, not in the resolution. The final clauses specify that the "rules, regulations and procedures drafted by the Preparatory Commission shall apply provisionally" from the date of entry into force of the Convention, "pending their formal adoption by the Authority in accordance with Part XI." ${ }^{65}$ Absent a guarantee that known rules, regulations, and procedures will enter into force along with the Convention, it is not

${ }^{161}$ While the conference will inevitably hope to avoid reopening "settled" issues, it is possible that a coalition of developing and developed countries that are interested in avoiding delay in the entry into force of the Convention may agree to reduce the number in the context of agreement on other matters designed to facilitate its entry into force.

${ }_{162}$ DC(IT) Art. 137.

${ }^{163}$ DC(IT) Ann. III, Art. 6, para. 1 and Art. 7, para. 1.

${ }_{164}$ UN Doc. A/CONF.62/L.55 and Corr.I (1980); Conf. Docs. PC/1, PC/2, and Corr.1 (1980).

${ }^{165} \mathrm{DC}(\mathrm{IT})$ Art. 308, para. 4. The significance of this provision is immediatel $y$ apparent when one considers that the new text of Article 161 requires consensus in the Council of the Authority for the adoption of rules, regulations, and procedures. 
clear how the major industrial states (and perhaps others with significant economic interests at stake) could be persuaded to ratify the Convention. The First Committee's "package" would be stripped of its content.

The clause regarding provisional application of the rules, regulations, and procedures drafted by the Preparatory Commission nevertheless contains a footnote that reflects some disquiet on this matter. One source of the disquiet is legal, namely, a certain reluctance to give legal effect, albeit provisionally, to rules drafted by the Commission without subsequent action by the Authority.

However, each state will review the entire package. Governments may accordingly insist upon scrutinizing the draft rules, regulations, and procedures together with the provisions of the Convention in making the decision whether to ratify the Convention. The legal basis for applying the rules provisionally is found not in the procedures and composition of the Preparatory Commission, but in the text of the Convention itself and the legal right of each state to accept or reject the entire package, including the provisional rules, regulations, and procedures.

Another source of disquiet is the proverb that in diplomacy, nothing is more permanent than the provisional. Since the provisional rules may actually be more carefully and intensively scrutinized by states than the permanent ones, one is tempted to ask what difference it makes. While it seems clear that the Authority has the power, if it wishes, to amend or supplement the provisional rules in the same way as it would amend or supplement the permanent rules, there may be merit in emphasizing this point in order to alleviate concerns about the period between entry into force of the Convention and adoption of a complete set of permanent rules by the Authority.

Ensuring that the Authority can function when the Treaty enters into force requires that the necessary organs be constituted. The text thus provides that the Assembly of the Authority shall meet on the date of entry into force of the Convention and shall elect the Council of the Authority. ${ }^{166}$ Article 161, however, requires that states that belong to certain specified interest groups and regional groups be members of the Council. What if the requisite number for entry into force has ratified the Convention, but it is not possible to fulfill one or more of the functional or regional group requirements regarding composition of the Council?

The conceptual solutions to the problem are either to make the criteria for Council composition criteria as well for entry into force of the Convention, or to provide for some deviation in Council composition so long as too few ratifications prevent the Council from being constituted as required by Article 161 .

The first option was rejected for a variety of reasons. ${ }^{167}$ The problem with the second option was that the decision-making procedures under consideration in the First Committee proceeded on the assumption that each of

\footnotetext{
ths DC(IT) Art. 308, para. 3.

${ }^{\text {it7 }}$ Substantively, it would have given the Soviet Union, but no other country, effective power to control entry into force of the Convention. Procedurally, it would have complicated the already deadlocked negotiations in the First Committee regarding Council voting.
} 
the relevant groups-particularly the substantive interest grcups-would be fully represented on the Council by the specified number of states. Any alteration in the composition of the Council could accordingly unbalance the voting formulas protecting the various interests. However, the seriousness of this problem has been significantly attenuated by the fact that under the new text, consensus is required for major decisions of the Council.

The Chairman of the Group of Legal Experts preferred the second option and recommended the following text: "The first Council shall be constituted in a manner consistent with the purposes of article 161 if the provisions of that article cannot be strictly applied." 168

The President decided to adopt that text. ${ }^{169}$ In addition, in an effort to reduce the likelihood of a problem, the new text also provides for a delay of 12 months after the date of deposit of the 60th instrument of ratification before the Convention enters into force. ${ }^{170}$ Thus, states will have an ad-

${ }^{168}$ Conf. Doc. FC/20 (1980). The precise language suggested by the Chairman of the Group of Legal Experts was not the subject of negotiation, since most debate concentrated on the underlying option.

It seems reasonably clear that the provision applies only in case it is impossible, from among the parties to the Convention, to satisfy all of the requirements regarding Council composition in a manner consistent with Article 161. It also seems reasonably clear that it deviation from strict compliance with Article 161 is only permissible to the extent it is necessary to deal with the effect of the absence from among parties to the Convention of one or more states necessary to satisfy a particular requirement.

While the term "first Council" is unclear, it also seems reasonably clear that the deviation from strict application of Article 161 can persist only as long as the absence that necessitated it persists. If a state ratifies the Convention after entry into force, and if its election to the Council would result in elimination of at least one reason for deviation from strict application of Article 161, then it should be elected to the Council as soon as practicable, and the arrangements made to deal with its absence eliminated.

What is not clear is the precise meaning of the phrase "in a manner consistent with the purpose of article 161." The main reason for this is that it is difficult to cletermine in advance the precise nature of the problem, given the large number of alternative possibilities. Since any deviation from the strict requirements of Article 161 could have a major effect on the legitimacy and effectiveness of the Authority during the delicate initial period of its existence, one presumes that all concerned would make every effort to ensure that the arrangements on Council composition command a consensus, including in particular the support of those states parties that are members of the group affected. The need to obtain the support of such states is, if not explicitly stated, then certainly implicit in the new provision in Article 161, paragraph 2(c), which specifies that each group of states parties to be represented on the Council is represented by those members, if any, which are nominated by the group.

${ }^{169}$ DC(IT) Art. 308, para. 3. The President of the conference, recognizing the close links between this issue and the negotiations in the First Committee regarding the Council, solicited the views of the Chairman of the First Committee on this matter during the resurned session. The First Committee Chairman recommended that "there be no modifications in the text pending further negotiations concerning article 161." It is possible to interpret that recommendation as meaning either no change from the current ICNT, which contained no provision dealing specifically with composition of the Council in connection with entry into force of the Convention (ICNT/Rev.2 Art. 301), or no change from the clause recommended by the Chairman of the Group of Legal Experts on Final Clauses. The President apparently chose the latter interpretation. The collegium as a whole, of course, decided on all the new articles incorporated into the DC(IT).

${ }^{170}$ DC(IT) Art. 308, para. 1. 
ditional 11 months in which to ratify in order to be parties when the Convention enters into force.

\section{Reservations}

The conference has approached the question of reservations in a way that reflects some basic differences between the emerging Convention on the Law of the Sea and other multilateral treaties.

First, whatever their different priorities, most states have engaged in the negotiations in a serious effort to make law on one point or another binding on other states. A major reason for seeking a rule of law in the first place is a concern that in its absence behavior might not conform to a desired norm, or any norm.

Permitting reservations would undermine these objectives with respect to parties to the Convention. It would also weaken any potential argument that the provision in question represents a rule of international law binding on all states, whether or not they are party to the Convention. A major maritime power could hardly be expected to agree to permitting reservations, for example, in derogation of basic navigational freedoms such as the right of transit passage through straits.

Second, even if such a result were politically acceptable (which is very doubtful), reservations to the most controversial part of the text-the deep seabed mining regime and machinery - would generally not be possible or efficacious for structural reasons. The organization and functions of the $\mathrm{Au}$ thority and the rules by which it operates must in principle be the same for all.

The major practical function of a reservation to a text like the deep seabed mining provisions is to make a statement on the record interpreting the text or giving notice to the organization and the other parties of certain expectations. Neither kind of statement is a true reservation. ${ }^{171}$ Thus, to the extent that the deep seabed mining regime is not one of the major positive features in the Treaty for a particular state, a liberal attitude on true reservations will do nothing significant to improve that situation, but may well undermine other provisions that state does find attractive.

Third, the very size and complexity of the Convention suggests only superficially the possible desirability of permitting reservations. Peering beneath the surface, one finds in much - if not all - of the details "safeguards" that were, and in most cases remain, a condition for agreement to more general or "basic" provisions. Representing as it does the result of a long-term shift in the law of the sea from a relatively "pure" dichotomy of regimes based almost exclusively on either a territorial or a nationality (flag) concept to a much more complex functionalism, in many respects the principles

${ }^{171}$ Under the Vienna Convention on the Law of Treaties, UN Doc. A/CONF.39/27 (1969), entered mto force Jan. 27, 1980, reprinted in 63 AJIL 875 (1969), 8 ILM 679 (1969), a reservation is defined as "a unilateral statement, however phrased or named, made by a State, when signing, ratifying, accepting, approving or acceding to a treaty, whereby it purports to exclude or to modify the legal effect of certain provisions of the treaty in their application to that State." Art. 2(1)(d). 
and the detail of the Convention are inseparable. Indeed, at least in some cases it may be said that the detail is its essence.

For these and related reasons, the general view in the conference was that in principle reservations either should be prohibited or should be permitted only in very limited and specified cases. ${ }^{172}$

It was generally recognized that a negotiation on reservations is in fact a negotiation on the substance of the issue dealt with by the article in question. Accordingly, the text-following the general trend of debate-provides that a reservation or exception may not be made "unless expressly permitted by other articles" of the Convention. ${ }^{\mathbf{1 7 3}}$

This conservative approach to the question of reservations emerged together with a liberal view regarding declarations or statement:s that are not properly regarded as true reservations under international law. Thus, declarations or statements at the time of signature or ratification are permitted without restriction as to name or purpose ${ }^{174}$ so long as they "do not

${ }^{172}$ An uninitiated observer listening to the debate might have reached a different conclusion, since a number of vocal speakers argued passionately in favor of some reservations. Upon closer analysis, however, one recognized that a large majority of those speakers were from one of two groups. Some spoke for delegations that have yet to reconcile themselves on the record to particular provisions to which there is simply no chance that reservations would be permitted (e.g., the 12-mile territorial sea, transit passage of straits, the protections for coastal state fisheries interests). Others-indeed the more numerous group-are dceply engaged in ongoing negotiations regarding delimitation of the economic zone and continental shelf between states with opposite or adjacent coasts. For substantive or tactical reasons, these delegations do not wish to close the door on the possibility of reservations to the delimitation articles (and perhaps to Article 121 on islands and rocks).

173 The explanatory memorandum of the President states that, for an articlc to be construed as permitting a reservation or exception, it must use the word. UN Doc. AJCONF.62/L.58 (1980).

The reference to exceptions is intended to cover the optional exceptions to the Convention's dispute settlement procedures set forth in Article 298. The reason for this reference to "exceptions" is basically political, not legal. It serves as a reminder that the chapter on settlement of disputes itself contains, as part of the substantive package, the functicnal analog to an elaborate provision on reservations to that chapter.

The reference to exceptions also enables delegations that oppose all reservations to accept the provision at present as drafted, since the final Convention (Art. 298) clearly will allow "exceptions" even if it does not allow reservations. Should there be no other article in the end that specifically permits reservations, the reference to exceptions preserves the technical accuracy of this article and thus could help save the conference from the potentially difficult task (albeit not the technical desirability) of achieving consensus on changing the text and deleting the cross-reference to other articles at the last minute. None of these political considerations, of course, may justify confusing reservations and exceptions from the perspective of legal draftsmanship.

A footnote states that the "article can be regarded only as provisional pending the conclu. sion of discussion on outstanding substantive issues such as that relating to the delimitation of maritime zones as between adjacent and opposite States and to settlement of disputes thereon, where the final solution might include provision for reservations" The footnote also states that the article is based on the assumption that the Convention will be adopted by consensus. Delimitation issues aside, the reference to consensus in this context is understood by some delegations to mean that the so-called transitional provision will not appear in the Convention.

${ }^{174}$ Including, but not limited to, "the harmonization of national laws and regulations with the provisions of" the Convention. 
purport to exclude or to modify the legal effect of the provisions of this Convention in their application to that State Party."175

\section{Relation to Other International Agreements}

The question of the effect of the new Convention on earlier treaties and of later agreements on the Convention, where the same states are party to both, is rife with legal complexity. The new texts ${ }^{176}$ deal with three general classes of agreements.

(1) Agreements, existing or future, "expressly permitted or preserved by other articles" of the Convention. Such agreements are not affected by the rules in the new article on this subject. There are many examples of such agreements in the text, perhaps the most frequently cited being bilateral agreements delimiting the economic zone or continental shelf between states with opposite or adjacent coasts. ${ }^{177}$

(2) Existing agreements. The Law of the Sea Convention would not alter rights and obligations under existing agreements:

- compatible with the Law of the Sea Convention, and

- that do not affect the enjoyment by other states parties of their rights or the performance of their obligations under the Law of the Sea Convention.

This rule states the basic principles regarding the effect of a later treaty on an earlier one. The text is derived from the Vienna Convention on the Law of Treaties. ${ }^{17 x}$

(3) Agreements made subsequent to the Law of the Sea Convention. No problem arises with respect to an agreement made subsequent to the Law of the Sea Convention if that agreement is compatible with the Convention and does not affect the rights and obligations of other parties. A problem would arise, however, if some of the parties to the Law of the Sea Convention agreed to modify or suspend any of its provisions as among themselves only. As in the Vienna Convention, ${ }^{179}$ there are two conditions such agreements must satisfy in order to protect the rights of other states parties:

- they must not relate to provisions of the Convention derogation from which is incompatible with the effective execution of the object and purpose of the Convention; and

- they must not affect the enjoyment by other states parties of their rights or the performance of their obligations under the Convention. ${ }^{\mathbf{1 8 0}}$

${ }^{135} \mathrm{DC}(\mathrm{IT})$ Art. 310 . This text is derived from the definition of a reservation in the Vienna Convention on the Law of Treaties, note 171 supra.

${ }^{x \text { to }}$ DC(IT) Art. 311.

17 Sez id., Arts. 74, para. 4 and 84 , para. 4.

iin Supra note 171, Art. 30. The rule regarding third parties is drawn from Art. 41(1)(b) rather than from Art. $30(4)(b)$.

1 is Art. 41.

1xus This provision also states that such agreements "shall not affect the application of the basic principles embodied in this Convention." DC(IT) Art. 311 , para. 3. This confusing clause does not weem to add anything not already contained in the two conditions. If the clause is re- 
Two special rules are added. The first specifies that the new Convention "shall prevail, as between States Parties, over the Geneva Converitions on the Law of the Sea of 1958."181 The second rule provides, "The States Parties to this Convention agree that there can be no amendments to the basic principle relating to the common heritage of mankind set forth in article 136 and that they shall not be party to any agreement in derogation thereof." 182 This provision was added in an effort to accommodate some of the concerns of delegations that unsuccessfully sought a provision declaring the common heritage principle to be a peremptory norm of international law. ${ }^{183}$ It applies expressly only to the "States Parties to this Convention" in order to emphasize the fact that it does not address the rights of states under international law and is not generally regarded as declaratory of, or designed to create, a peremptory norm under customary international law. ${ }^{184}$

\section{Amendments and Denunciation}

The question of amendments involves reconciling the desire for stability and uniformity that provides a major impetus for ratifying the Convention with the undoubted need for some flexibility and responsiveness to change. The problem of preserving consensus lies at the heart of the matter. There are a wealth of interests shared by only a few states that are protected by one or another provision of the Convention. For these states, such provisions are a critical part of the overall consensus package.

Three techniques for dealing with the problem were considered by the conference. First, one can specify procedures applicable to the adoption (preparation) and entry into force of amendments that encourage consensus, or that otherwise make it difficult to ignore interests specifically affected by an amendment simply because they are shared only by a minority of states. However, to the extent flexibility is the relevant consideration, one would have to stop short of a rigid requirement of universal ratification

tained, the use of the term "shall not" distinguishes it from the term "do not," which appears before the two conditions for such agreements, and therefore provides the te:stual basis for concluding that it is an elaboration on the effect of the two conditions rather than an additional condition.

${ }^{181}$ This text emerged from a surprisingly unemotional and nonideological debate about the value of the 1958 Geneva Conventions in general. The text means that the new Convention prevails in its entirety over the old, but that it is properly interpreted against the background of the 1958 Geneva Conventions, which constituted either the basis or the poinl. of departure for most of the new Convention.

${ }_{182} \mathrm{DC}(\mathrm{IT})$ Art. 311 , para. 6.

${ }^{183}$ See 74 AJIL at 38-40; Vienna Convention, note 171 supra, Arts. 53, 64.

184 It also does not restrict the right of parties to the Convention to be party to pirior or future agreements regarding deep seabed mining so long as the agreements are applied in a manner that does not derogate from the provisions of Article 136 and that is consistent with the general rules set forth in Article 311 regarding other agreements. An interesting question could conceivably arise regarding commodity agreements that have an effect (albeit indirect) on seabed production or prices to which the Authority is not a party. It is possible that upon reflection this tempered the enthusiasm for a jus cogens provision among land-based producers of minerals. 
before the amendment could enter into force. Moreover, with respect to specially affected interests, there is a technical problem in attempting to catalog in advance all the particular interests specially affected by particular provisions of the Convention.

Second, one can provide that an amendment only enters into force for those states that ratify it. A state's interests in controlling any alteration in its treaty obligations are thus protected. However, its interests in the overall stability and uniformity of the law of the sea are not. Over time it could become difficult to resist a majority practice legitimized by an amendment. Moreover, this technique is not available where the same rules must apply to all parties for structural reasons.

Third, the right of a state to denounce the Convention can be set forth so as to operate as a restraint on the willingness of others to adopt an amendment. This is a blunt instrument that is undoubtedly effective in averting serious prejudice to a major interest. It is not the most desirable technique for "fine tuning" routine amendments.

The Convention applies all three techniques. It expressly confirms the right of a state to denounce the Convention on 1 year's notice. ${ }^{185}$ Thus, the third technique is available, if need be, to discourage all adverse amendments and other actions.

The first two techniques are also applied, but in different ways to two different categories:

(1) "amendments other than those relating to activities in the Area"; and

(2) "amendments relating exclusively to activities in the Area."

"Activities in the Area" is a defined term that refers to deep seabed mining (seaward of the continental shelf). ${ }^{186}$ The two categories of amendments are mutually exclusive with no overlap. ${ }^{187}$

Amendments other than those concerning deep seabed mining. With respect to this first category of amendments, a state party may request that a conference of states parties be convened to consider "specific amendments" once the Convention has been in force for more than 10 years. ${ }^{188}$ The

\footnotetext{
185 DC(IT) Art. 317.

196 "Activities in the Area" is defined as "all activities of exploration for, and exploitation of, the resources of the "Area." DC(IT) Art. 1. The "Area" is defined as the seabed and ocean floor and subsoil thereof beyond the limits of national jurisdiction. Ibid. While this is generally understoad to mean the seabed and subsoil beyond the limits of the continental shelf, as defined in Article 76 (except pursuant to Article 121(3) in the case of certain rocks), the Drafting Committee is still considering the matter.

${ }^{187}$ The first category applies to amendments relating only to matters other than activities in the Area. The absence of the word "exclusively" from the first category is correct. It would be incorrect to state that the first category applies to amendments other than those relating "exclusively" to activities in the Area, as this would permit the procedures applicable to the first category to be used for "mixed" amendments to circumvent the procedures applicable to the second category. While the text of the DC(IT) is accurate, one could also delete the word "exclusively" from the second category without changing the meaning.

${ }^{28}$ DC(IT) Art. 312, para. 1.
} 
amendment conference would be convened if a majority of states parties respond affirmatively to the request within 12 months. Its decision-making procedures would be the same as those applicable at the current Law of the Sea Conference, expressly including the requirement contained in the Gentleman's Agreement ${ }^{189}$ that the "conference should make every effort to reach agreement on any amendments by way of consensus and there should be no voting on such matters until all efforts at consensus have been exhausted."190

Alternatively, an amendment in the first category may be circulated directly to states parties for adoption by a simplified procedure without convening a conference and without any 10-year delay. If within 12 months no state party objects to the proposed amendment or its adoption by a simplified procedure, then it is considered adopted. ${ }^{191}$

In either case, amendments are subject to ratification. ${ }^{192}$ The amendment enters into force only for the states ratifying it, after it has been ratified by two-thirds, but not less than 60 , of the states parties. ${ }^{193}$

There was substantial support for the idea of adding qualitative requirements for entry into force of amendments affecting particular interests of various categories of states, but the endeavor proved difficult and complex. Instead, the consensus requirement was added to the provision on conference procedures, and the question of additional requirements for entry into force was left to be dealt with in connection with the negotiation of the amendment itself, at which time it would be easier to ascertain the precise effect of the amendment on different groups. Thus, an amendment may specify a "larger number of ratifications" for its entry into force than the minimum required by the Convention itself. ${ }^{194}$

Deep seabed mining amendments. With respect to deep seabed mining, the main question concerned the possible need for amendments during the approximately 20 years prior to the review conference provided for in the deep seabed mining texts. ${ }^{195}$ The Sea-Bed Authority was considered the appropriate place to consider such amendments in light of its expertise and because its decision-making procedures were being designed to protect all relevant interests.

Accordingly, a state party may propose an amendment relating to deep seabed mining at any time. It would be referred to the Council of the Authority, and would be considered adopted only if the identical text were approved by both the Council and the Assembly. ${ }^{196}$ Consensus is required for approval of amendments in the Council. ${ }^{197}$ Before approving an amend-

\footnotetext{
${ }^{189}$ Appended to the Rules of Procedure, UN Doc. A/CONF.62/30/Rev.2 (19\%6), reprinted in 73 AJIL. 3 n. 11.

190 DC(IT) Art. 312, para. 2. 191 Id., Art. 313.

${ }^{192} I d$. . Art. 315, para. 2. See note 160 supra.

${ }^{193}$ DC(IT) Art. 316, para. 1.

${ }^{194}$ Given its negotiating history as an effort to accommodate those favoring qualitative requirements, the term "larger number" is properly understood to refer to qualitative as well as quantitative requirements additional to those specified in the Convention.

195 DC(IT) Art. 155. ${ }^{196}$ Id. , Art. 314.

${ }^{197} I d .$, Art. 161, para. 7(d).
} 
ment, the Council and the Assembly must determine that it does not prejudice the system of exploration and exploitation pending the review conference.

Seabed mining amendments, like all others, are subject to ratification. ${ }^{198}$ However, by their very nature, they must enter into force for all parties at the same time. The Authority cannot function under different treaty provisions with respect to different states.

Accordingly, if a seabed mining amendment approved by the Council and the Assembly is ratified by three-fourths of the states parties, it enters into force for all states parties 1 year later. ${ }^{199}$ The 1 -year delay is designed to give a state that has not ratified the amendment time to decide whether it will ratify the amendment in accordance with its constitutional procedures, allow the amendment to enter into force for it without ratification, or denounce the Convention. ${ }^{200}$

\section{Participation and the Transitional Provision}

At the suggestion of its President, the conference deferred debate on the question whether entities other than states may become party to the Convention and on the fate of the "transitional provision" that currently appears after the text of the Convention. ${ }^{201}$ The author's earlier discussion of the substance of these problems need not be repeated here. ${ }^{202}$

There is some evidence that the European Economic Community is trying to find a way to deal with the problem of reciprocity of obligations that might arise if an economic community (not necessarily the European Community) is a party to the Convention with respect to matters within its competence, but one of the member states of the community is not a party to the Convention (with respect to matters that remain within its competence).

With respect to liberation movements, it should be recalled that 60 ratifications are required for entry into force of the Convention. Many states will wish to review the rules, regulations, and procedures drafted by the Preparatory Commission before deciding on ratification. Thus, it is unlikely that the Convention will enter into force before the mid-1980's. Under these

${ }^{19 \kappa} I d .$, Art. 315, para. 2.

${ }^{144}$ Amendments to Annex VI, the Statute of the Law of the Sea Tribunal, also enter into force for all states parties. Such amendments can only be adopted by consensus at a conference or by the simplified "no objection" procedure, or, in the case of the Sea-Bed Disputes Chamber, by the procedure applicable to seabed mining amendments. DC(IT) Ann. VI, Art. 42.

${ }^{200}$ There was also some private discussion of whether states could withdraw their instruments of ratification during the 1-year period in order to avert denunciation of the Convention by others. One suggestion was that it might be prudent for seabed mining amendments to contain a provision authorizing the Council of the Authority to delay their implementation where necessary to avoid prejudice to the effectiveness or universality of the Convention, or simply authorizing the Council to fix the date for their application after their entry into force.

201 The transitional provision accordingly is not a part of the Convention pursuant to Article 318 , which incorporates only the annexes by reference.

20274 AJIL $40-45$. 
circumstances, is it not possible to view an insistence that liberation movements be allowed to become parties as a tacit admission that they are not expected to be in any different position by the mid-1980's? Is this not political reason enough to avoid pressing the issue?

Supporters of the Convention face a difficult battle for ratification, given the widespread fears regarding the Sea-Bed Authority. They cannot afford to antagonize those who as a matter of principle or politics are unlikely to support a treaty with liberation movements in general or the Palestine Liberation Organization in particular. What is needed is a solution that frees the Convention of these issues while giving maximum possible scope to the expression of political sentiments regarding national liberation and decolonization. One may speculate that possible elements of such a solution might include the following:

- Along with states, regional economic communities to which states have transferred competence and certain associated states could be parties to the Convention. The relevant legal instrument for determining whether they have the necessary internal and external competences would be the constitutive agreements with or among states, be it the agreements establishing an economic community or the agreements defining the basic relationship between a state and an associated state.

- Observers at the conference would in principle be accorded similar status in organs established by the Convention such as the Assembly of the Sea-Bed Authority.

- A resolution adopted by consensus would affirm the obligations of states with respect to the lawful inhabitants of areas under foreign occupation and dependent territories, in particular as regards the natural resources of the territorial sea, economic zone, and continental shelf.

\section{The Drafting Committee}

During the ninth session, and a 3-week meeting in New York in June, the Drafting Committee continued and largely completed its work on harmonization of terms identified in various papers prepared at its request by the Secretariat. ${ }^{203}$ This work was conducted through the six language groups, with the Chairman of the committee and the coordinators of the language groups endeavoring to work out generally acceptable results.

The exercise was productive. However, it revealed considerable reluctance to change the text. This reluctance continues as the Drafting Committee now undertakes an article-by-article textual review in six languages. The result is certain to be a document with a number of legal drafting problems about which nothing has been done. The United States delegation

\footnotetext{
${ }^{203}$ The reports of the Drafting Committee are in UN Docs. A/CONF.62/L.40 (1979), L.56, L.57/Rev.1, and L.63/Rev.1 and Corr.1 (1980). The conference documents containing the reports of the six language groups were initially identified by the symbol LGDC, but soon were divided as follows: ALGDC (Arabic), CLGDC (Chinese), ELGDC (English), FLGDC (French), RLGDC (Russian), and SLGDC (Spanish). This article was completed prior to the meeting of the committee that began Jan. 12, 1981 .
} 
drew attention to this point, noting the routine clause that the text is equally authentic in all six languages ${ }^{204}$ and the assumptions regarding the nature of the work in the Drafting Committee that lay behind such a clause. Almost every article not copied verbatim from another treaty was negotiated in English and translated into the other languages by the Secretariat after the fact, in many cases very rapidly at the end of a session.

The Drafting Committee will not easily find solutions to the many problems of harmonization, concordance, and consistency that exist throughout the text. The resulting situation may inevitably yield a rule for interpreting this large and complex Convention not far removed from the following formulation suggested lightheartedly by one participant: the use of the same terms in different places does not necessarily indicate that the same meaning is intended; the use of different terms in different places does not necessarily indicate that a different meaning is intended.

\section{Conclusion: The Preamble}

During the first part of the ninth session, the Informal Plenary devoted several meetings to the Preamble. Views were divided between those who preferred a short preamble such as that contained in the ICNT and those who preferred a longer and more philosophical preamble. ${ }^{205}$

The Preamble ultimately adopted contains a succinct statement of the immediate purposes of the "legal order for the seas and oceans" established by the Convention. It begins with a reference to facilitating the traditional uses of the seas for international communication. For the first time in a global international convention of this sort, it mentions not only "equity" but "efficiency" as the purpose of that legal order with respect to utilization of ocean resources. ${ }^{206}$ It expressly affirms that the achievement of "such goals"-including in addition the "study, protection and preservation of the marine environment" - will "contribute to the realization of a just and equitable international economic order." The view that there is an inherent contradiction among these various objectives is thus rejected. ${ }^{207}$

$$
{ }^{204} \mathrm{DC}(\mathrm{IT}) \text { Art. } 320 .
$$

205 The concern of the former group was that the negotiation of a long preamble could revive and stimulate ideological disputes and bog down in efforts by delegations to color the interpretation of the substantive articles. The structural accommodation successfully pursued by the President involved a somewhat longer preamble than in the ICNT, but on the understanding that objectionable "code words" could not be used, and that the Preamble could not reflect or emphasize only one point of view.

206 While economists may differ as to whether all aspects of the Convention are fully consistent with those goals, the important point is that to the extent the Preamble is a guide to the values to be applied in interpreting the text of the Convention, those values include both equity and efficiency in utilization of ocean resources.

${ }^{207}$ Two interesting drafting problems arose. One concerned the verb to be used in referring to the principles contained in the Declaration of Principles Governing the Sea-Bed and Ocean Floor, and the Sub-soil thereof, beyond the Limits of National Jurisdiction, GA Res. 2749 (XXV) (1970). The declaration calls for a convention to "give effect" to the principles. Some countries feared that the use of such a term might be interpreted to imply that the principles can be ignored pending entry into force of the Convention. The conference settled naturally 
Perhaps the most important clause in the Preamble is the reminder that the underlying purpose of a convention setting forth basic rules of law and dispute settlement mechanisms binding on all is to "contribute to the strengthening of peace, security, co-operation and friendly relations among all nations."

Members of the legal profession, particularly those learned in the history and philosophy of law, might well regard such a statement as obvious and trite. Yet the debate on the Convention, even in the United States and some Western European countries, is so barren of reference to the values inherent in law and order as to raise disquieting doubts about the commitment to these traditional Western values. Public order is a basic requirement, even (or perhaps especially) for rational economic man.

The weight to be accorded these considerations will determine the fate of the Convention. Such values were central to the extraordinary moral leadership of the conference demonstrated by its late President, Ambassador Hamilton Shirley Amerasinghe.

enough on the verb summum bonum: "Desiring by this Convention to develop the principles $\mathrm{cm}$ bodied in" the declaration (emphasis added).

The second problem concerned the ICNT preambular clause that matters not regulated by the Convention continue to be governed by "customary international law." While the substance of the principle was generally acceptable, in the course of the technical redrafting the term was changed to "general international law" because a few delegations from newly independent countries had a philosophical aversion to the implication of antiquity in the word "customary." 